\title{
THE NEW BASEL CAPITAL FRAMEWORK AND ITS IMPLEMENTATION IN \\ THE EUROPEAN UNION
}

by Frank Dierick, Fatima Pires, Martin Scheicher and Kai Gereon Spitzer 
E U R PEAN CENTRAL BANK

\title{
OCCASIONAL PAPER SERIES
}

NO. 42 / DECEMBER 2005

\section{THE NEW BASEL CAPITAL FRAMEWORK AND ITS IMPLEMENTATION IN THE EUROPEAN UNION *}

\author{
by Frank Dierick', \\ Fatima Pires ', \\ Martin Scheicher ${ }^{2}$ \\ and Kai Gereon Spitzer ${ }^{3}$
}

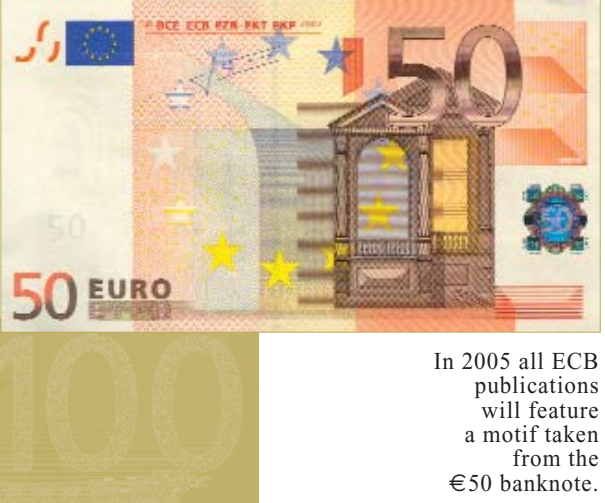

This paper can be downloaded without charge from the ECB's website (http://www.ecb.int) or from the Social Science Research Network electronic library at http://ssrn.com/abstract_id=8074l 6 .

* The authors are grateful for research assistance by Sara Testi and comments by Mauro Grande, Panagiotis Strouzas and an anonymous referee. The views expressed in this paper are those of the authors and do not necessarily reflect those of the $E C B$, the Eurosystem or the Deutsche Bundesbank. 


\section{(C) European Central Bank, 2005}

\section{Address}

Kaiserstrasse 29

60311 Frankfurt am Main

Germany

\section{Postal address}

Postfach 160319

60066 Frankfurt am Main

Germany

Telephone

+496913440

Website

http://www.ecb.int

Fax

+496913446000

Telex

$411144 \mathrm{ecb} d$

All rights reserved. Any reproduction, publication and reprint in the form of a different publication, whether printed or produced electronically, in whole or in part, is permitted only with the explicit written authorisation of the $E C B$ or the author(s).

The views expressed in this paper do not necessarily reflect those of the European Central Bank.

ISSN 1607-1484 (print)

ISSN 1725-6534 (online) 


\section{CONTENTS}

\section{ABBREVIATIONS}

ABSTRACT

\section{EXECUTIVE SUMMARY}

INTRODUCTION

PART I - OVERVIEW OF THE NEW FRAMEWORK

I DEVELOPMENT

2 STRUCTURE

2.1 General overview

2.2 Pillar I - Minimum capital requirements

2.3 Pillar II - Supervisory review process

2.4 Pillar III - Market discipline

3 THE NEW FRAMEWORK IN THE EU

3.1 Legal and institutional setting

3.2 Specific features of EU implementation

PART II - ISSUES OF SPECIFIC RELEVANCE IN THE EU CONTEXT

4 PROCYCLICALITY

4.1 Definition

4.2 Empirical evidence

4.3 Mitigating measures

4.4 Monitoring in the EU

5 HOME-HOST ISSUES AND THE

CONSOLIDATING SUPERVISOR

5.1 International and European context

5.2 Powers and responsibilities of the consolidating supervisor

5.3 Assessment of the consolidating supervisor
6 REAL ESTATE LENDING

6.1 Overview 37

5

6.2 Residential real estate 38

6.3 Commercial real estate $\quad 40$

7 COVERED BONDS 4I

7.1 Concept of covered bond 4I

7.2 Capital treatment 42

CONCLUDING REMARKS 43

GLOSSARY $\quad 45$

$\begin{array}{ll}\text { REFERENCES } & 48\end{array}$ 


\section{ABBREVIATIONS}

AIG Accord Implementation Group

AMA advanced measurement approaches

ASRF asymptotic single risk factor

BCBS Basel Committee on Banking Supervision

CAD Capital Adequacy Directive (93/6/EEC)

CBD Codified Banking Directive (2000/12/EC)

CEBS Committee of European Banking Supervisors

CP consultative paper

CRD Capital Requirements Directive

CRE commercial real estate

EAD exposure at default

ECAI external credit assessment institution

ECB European Central Bank

EFR European Financial Services Round Table

EU European Union

FSAP Financial Services Action Plan

IRB internal ratings-based

LGD loss given default

M effective maturity

MiFID Markets in Financial Instruments Directive (2004/39/EC)

PD probability of default

QIS quantitative impact study

RRE residential real estate

SMEs small and medium-sized enterprises

S\&P Standard \& Poor's

UCITS Undertakings for Collective Investment in Transferable Securities 
Following the adoption by the Basel Committee of new capital rules for banks, a process is now taking place in the EU to transpose the rules into Community law and, ultimately, into national legislation. This paper gives an overview of the main issues that relate to the EU implementation, mainly from the perspectives of financial stability and financial integration. Although the EU rules are to a large extent based on the texts of the Basel Committee, modifications have been introduced to account for the specific legal and institutional setting, as well as for some features of the European financial system. The paper gives an overview of these modifications and deals in greater detail with a number of selected topics: the monitoring of procyclicality, the role of the consolidating supervisor and the treatment of real estate lending and covered bonds. The paper concludes with an outlook for the future.

Key words: banks, Basel II, capital requirements, financial regulation, financial stability, financial supervision, risk management.

JEL classification: G21, G28 


\section{EXECUTIVE SUMMARY}

In June 2004, the Basel Committee on Banking Supervision published its new capital rules for banks ("Basel II"). Recently, the European Parliament and the Council approved legislation transposing these rules into Community law and this legislation will, in turn, be transposed into national law. The European Central Bank (ECB) has an interest in these developments because of their possible implications for financial supervision, financial stability and financial integration. As well as providing a non-technical overview of the main elements of the new framework, this paper focuses on issues related to the European Union (EU) implementation. The paper is structured in two parts. Part I gives an overview of Basel II and the main issues that are relevant for its implementation in the EU. Against this general setting, Part II deals in greater detail with a number of selected topics that are particularly important for the EU: the monitoring of procyclicality, the role of the consolidating supervisor and the treatment of real estate lending and covered bonds.

Basel II is based on three mutually reinforcing pillars: minimum capital requirements (Pillar I), the supervisory review process (Pillar II) and market discipline (Pillar III). A main innovation is that a set of increasingly sophisticated approaches is now available to banks to calculate their minimum capital requirements. Although the simplest method to calculate capital for credit risk is based on assessments by rating agencies, under the most advanced approaches, banks are allowed to use their own estimated risk parameters. Moreover, for the first time, banks are required to hold capital for operational risk.

While the EU rules are to a very large extent similar to those developed by the Basel Committee, they are not an exact copy. First, the legal and institutional setting is different. The EU rules are legislative in nature and binding in all Member States. Moreover, the recently established Committee of European
Banking Supervisors (CEBS) will play a major role in developing supervisory guidance to implement the new rules. Second, the specific structure of the European financial system, such as the role of the Single Market, justifies certain deviations.

The EU rules diverge from Basel II in their scope of application and the range of approaches that will be available to institutions to calculate their capital requirements. They also change the supervisory responsibilities by giving a larger role to the consolidating supervisor and by requiring supervisory disclosure. In the Single Market there is a greater need for cooperation between supervisors. Some specific features of the EU economy and financial system need to be addressed as well. This includes venture capital, real estate lending and covered bonds. In addition, the EU rules provide for specific arrangements concerning the issue of procyclicality. Empirical evidence indicates that capital rules can indeed exacerbate the economic cycle. However, in the development of the new rules various changes were made to accommodate these concerns. A study performed under the auspices of the European Commission confirmed that procyclicality should no longer be a major problem, although it should be kept under review. To that end, the EU rules provide for a monitoring arrangement that also involves the ECB.

In more detail, the EU rules provide for an enhanced role of the consolidating supervisor, in particular, through the process of approval of advanced methods to calculate capital requirements on a group-wide basis. Although this extended role does not go as far as some large financial groups would like, it will simplify the interaction between the banking group and its supervisors as well as between the various supervisors. It is also likely to be beneficial for financial stability and integration, although it raises complex implementation issues that will need to be followed up closely. 
Real estate lending is another important area given its significance in bank lending and that banking crises have often coincided with crises in the real estate market. In the treatment of real estate lending, the EU rules seem to achieve greater consistency than Basel II, although this leads to a somewhat less conservative treatment of commercial real estate lending. From a financial stability perspective, however, it is important that this more lenient treatment does not apply to the more risky real estate, the income of which is used for debt servicing. Some of the rules offer further scope for supervisory convergence, which would be beneficial for the integration of real estate lending in Europe.

Covered bonds receive a specific treatment under the EU rules that is not present in Basel II. These financing instruments, with the "Pfandbrief" as its best-known exponent, are important for EU capital markets. This preferential treatment, reflecting the additional security inherent in these bonds, is fully consistent with the principles underlying Basel II. It also seems that most of the existing covered bonds in the EU would qualify for this preferential treatment.

This paper concludes by listing some key challenges for the capital rules, first, as regards their EU implementation and, second, in a long run perspective. In the longer term, the definition of regulatory capital and its interaction with the new accounting rules will have to be addressed. Other areas which may warrant further study relate to the blurring of the border between credit risk and market risk, and the possible use of full credit portfolio models by banks to calculate their capital requirements.

\section{INTRODUCTION}

In June 2004, the Basel Committee on Banking Supervision (BCBS) published its new solvency rules for banks ${ }^{1}$, the New Capital Framework ("Basel II"). ${ }^{2}$ A parallel process has taken place in the EU to transpose the internationally agreed capital standards into Community law. Member States will also have to transpose the EU rules into national legislation in due course.

The ECB has an interest in these new rules because of its responsibilities in the areas of financial supervision and financial stability. ${ }^{3}$ The New Framework may also affect the Eurosystem credit operations through its rules for ratings assigned to financial assets used as collateral for such operations. ${ }^{4}$ In addition, the proposed EU rules provide for arrangements to monitor the macro-economic impact of the New Framework, which includes a specific role for the ECB. Finally, the implementation of the new solvency rules may have implications for financial integration, a Community objective that is supported by the ECB. The ECB was actively involved in the discussions on the new rules through its participation in the BCBS and European fora, and via its policy advice. ${ }^{5}$

This paper aims to give an overview of the main issues related to the implementation of the New Framework in the EU, especially from the perspectives of financial stability and financial integration. Although the proposed EU rules are to a large extent similar to the ones developed by the Basel Committee, they are not an exact copy of them. First, the legal and institutional setting is different. The EU framework is legislative in nature and therefore binding in all Member States. Moreover, account has to be taken of the new regulatory and supervisory set-up in the EU as a result of the extension of the "Lamfalussy framework" to the banking sector. Second, the specific features of the European financial system, such as the role of the Single Market, justify some deviations.

1 In this paper, the term "bank" is used as a synonym for "credit institution".

2 Basel Committee on Banking Supervision (2004a).

3 Art. 105(5) of the Treaty establishing the European Community.

4 See in this respect ECB (2005a)

5 See in particular ECB (2005b). 
This paper is structured in two main parts. The first one deals with the Basel Framework and its implementation in the EU and the second one addresses certain topics that are particularly important in the EU context. In Part I, Section 1 briefly recalls the main steps that were taken in finalising the Basel II Framework and Section 2 provides an overview of its main elements. In Section 3, the EU implementation of Basel II is discussed in general terms. It starts by recalling the specific legal and institutional setting in the EU and then turns to the main differences between the Basel and the EU rules.

Part II builds on this general analysis and singles out a number of areas, which are of particular relevance for the EU, and investigates them in greater detail. Section 4 tackles the issue of procyclicality, i.e. the concern that the new capital rules may exacerbate economic cycles. It reviews the empirical evidence, the different measures to mitigate such effects and the specific monitoring arrangement provided for under the EU rules. Implementation issues in a crossborder context are analysed in Section 5. Here, the EU rules diverge from Basel by enhancing the role of the authority responsible for supervision on a consolidated basis. Section 6 compares the EU and Basel rules in their treatment of real estate collateral, both for residential and commercial real estate lending. The treatment of covered bonds, a financing instrument that is particularly popular in the EU, is dealt with in Section 7. The paper concludes by giving a future outlook as Basel II and its implementation in the EU represent very important steps in a longer term process, but not its end.

\section{PART I - OVERVIEW OF THE NEW FRAMEWORK}

\section{DEVELOPMENT}

With its New Framework for capital requirements, the BCBS aims to alleviate some of the drawbacks of the current regime dating back to 1988 ("Basel I"). ${ }^{6}$ First, the current
Basel I rules offer a simplified and rigid quantification of credit risk, that are not in line with best practices applied by banks in their risk management. Basel II significantly refines the framework's risk sensitivity by requiring higher levels of capital for high-risk borrowers. By aligning required capital more closely to a bank's own risk estimates, the New Framework narrows the gap between regulatory capital and economic capital (requirements). ${ }^{7}$ It therefore encourages banks to improve their risk assessment methods. Furthermore, the increasing use of risk mitigation and securitisation has created the need to treat them more extensively. Another drawback of the current framework stems from its unintended incentives for capital arbitrage through techniques such as securitisation. In addition, the current framework lacks rules for proper market disclosure and therefore does not support market discipline. Finally, it offers no guidance for the supervisory review of banks' risk management practices.

Work on the New Framework started after 1996 when the Capital Accord underwent a major amendment to introduce capital requirements for market risk. ${ }^{8}$ At the current juncture, full implementation of the Basel II Framework is expected for the end of 2007. The whole process, therefore, from the initiation of discussions to the moment when the most advanced calculation methods will become available, will have stretched out over more than a decade.

Box 1 lists the key development stages and the next steps in the implementation. The development process was characterised by an intensive dialogue with the banking industry, reflected in the various consultation papers published by the BCBS. The Basel Committee also carried out several quantitative impact

6 Basel Committee on Banking Supervision (1988). Basel I is also called the "Basel Capital Accord".

7 Regulatory capital is capital that is eligible to meet regulatory capital requirements; economic capital is capital held by the bank internally as a result of its own risk assessment. Technical terms are explained in the glossary at the end of the paper.

8 Basel Committee on Banking Supervision (1996). 


\section{Box I}

\section{CHRONOLOGY OF THE BASEL PROCESS}

$\begin{array}{ll}\text { June 1999 } & \text { First Consultation Paper (CP1) } \\ \text { July 2000 } & \text { Quantitative Impact Study 1(QIS1) } \\ \text { January 2001 } & \text { Second Consultation Paper (CP2) } \\ \text { April 2001 } & \text { Quantitative Impact Study 2 (QIS2) } \\ \text { November 2001 } & \text { Quantitative Impact Study 2.5 (QIS2.5) } \\ \text { October 2002 } & \text { Quantitative Impact Study 3 (QIS3) } \\ \text { April 2003 } & \text { Third Consultation Paper (CP3) } \\ \text { 2004/2005 } & \text { Quantitative Impact Studies 4 and 5 (QIS4/5) } \\ \text { January 2004 } & \text { "Madrid compromise" } \\ \text { June 2004 } & \text { Publication of the "New Framework" document } \\ \text { April 2005 } & \text { Consultation on the trading book review and double default } \\ \text { July 2005 } & \text { Publication of the trading book review and double default } \\ \text { Spring 2006 } & \text { Scheduled recalibration of the New Framework } \\ \text { End 2006 } & \text { Scheduled G10 implementation of simpler methods } \\ \text { End 2007 } & \text { Scheduled G10 implementation of advanced methods }\end{array}$

studies to gauge the impact of the new rules on banks' solvency positions and further refine the rules.

Basel II has been designed as an evolutionary framework, so updates will be made over time to keep pace with ongoing developments in the financial industry. Prior to the implementation of the new rules, the Framework may undergo a quantitative adjustment ("recalibration") on the basis of the results of the most recent impact studies. In addition, some technical changes were introduced after June 2004 to address the "double default" issue and to bring the treatment of trading activities more in line with the New Framework. ${ }^{9}$ In the longer term, the BCBS intends to address a number of other areas which are discussed in greater detail in the last section dealing with the future outlook.

\section{STRUCTURE}

\section{I GENERAL OVERVIEW}

An overview of the New Framework and its main components is shown in Chart 1 . The dark boxes, which will be discussed in greater detail below, refer to the components that have been introduced or to which there are major changes as a result of the new rules; the bright boxes refer to the components that have remained unchanged. Whereas Basel I only covered minimum capital requirements, the Basel II Framework now rests on three complementary pillars, namely minimum capital requirements (Pillar I), the supervisory review process (Pillar II) and market discipline (Pillar III). In order to effectively support financial stability, the Framework requires a smooth interaction between all three pillars.

As regards Pillar I, the minimum solvency ratio of $8 \%$ remains unchanged. This ratio expresses the relationship between the bank's regulatory own funds (capital) and its "risk-weighted assets", a measure of the risks it incurs. Riskweighted assets are asset values multiplied by a factor (risk weight) that is a proxy of the (credit) risk related to these assets. For operational risk and market risk, the two other risk categories

9 Basel Committee on Banking Supervision (2005b). "Double default" refers to the fact that the risk of both a borrower and a guarantor defaulting on the same obligation may be substantially lower than the risk of only one of the parties defaulting; this feature is not sufficiently recognised in the June 2004 Framework. 


\section{Chart I Overview of the New Framework}

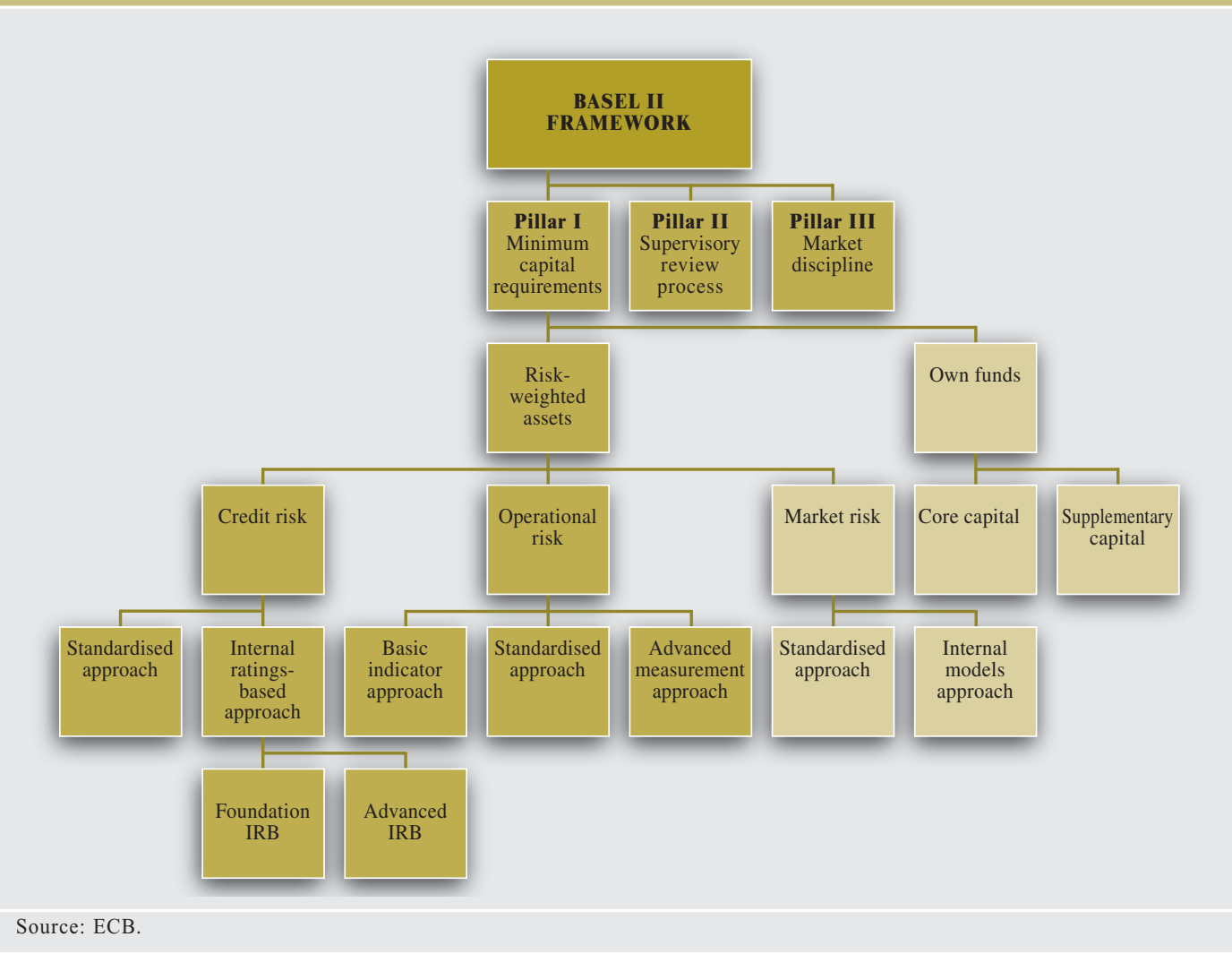

covered by the Framework, the risk-weighted assets that enter into the capital ratio are derived from the directly calculated capital requirements by multiplying them by 12.5 (the reciprocal of the minimum ratio of $8 \%$ ). In addition, the definition of regulatory capital (the numerator of the capital ratio) was basically unaffected.

Pillar I, however, provides a fundamental update of the Basel I methodology for the calculation of risk weighed assets, the denominator of the capital ratio. First, operational risk is introduced as a new risk category for which the bank has to hold regulatory capital. This risk category comprises losses resulting from inadequate or failed internal processes, people or systems, or from external events.

Second, a range of increasingly sophisticated and risk-sensitive options are now available for determining banks' capital requirements, both for credit risk and operational risk. In this way, the option can be chosen that best suits the bank's specific features. Moreover, incentives are in place for banks to adopt the more sophisticated approaches and thus improve their risk management capabilities over time. ${ }^{10}$ In the area of credit risk, two methods are available, namely the standardised approach and the internal ratings-based (IRB) approach. The former ties risk weights to ratings provided by recognised rating agencies. The latter uses banks' own estimates of certain risk factors; depending on the risk factors they are allowed to estimate, a distinction is made between a "foundation" and an "advanced" approach. The new rules for credit risk also cover a detailed treatment of securitisation and credit risk mitigation. Finally, in the area of operational risk, a bank can

10 For example the QIS3 results for the EU showed that institutions adopting the standardised approach would face an increase in capital requirements of $2 \%$, while those adopting the foundation IRB and the advanced IRB approaches would see a decline of $7 \%$ and $9 \%$ respectively. See European Commission (2003a) 


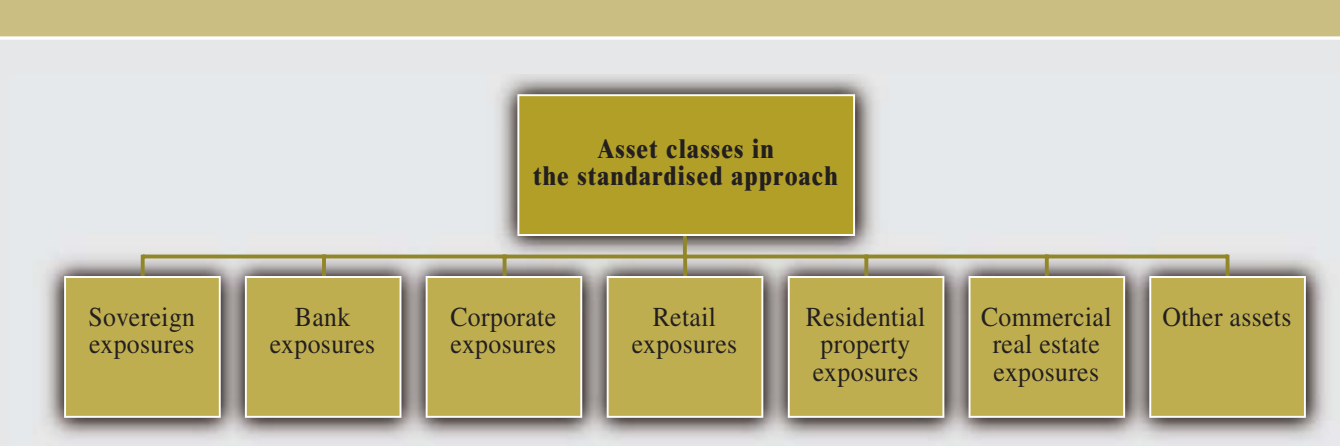

Source: ECB.

calculate its capital requirements on the basis of its gross income (basic indicator approach and standardised approach) or by using its own model (advanced measurement approach). As regards market risk, the New Framework leaves the existing approaches basically unchanged.

\subsection{PILLAR I - MINIMUM CAPITAL REQUIREMENTS}

\subsection{CAPITAL REQUIREMENTS FOR CREDIT RISK}

\section{(a) Standardised approach}

The standardised approach is closest to the present capital rules. Exposures are classified into a set of standardised asset classes (see Chart 2) and a risk weight is applied to each class, reflecting the relative degree of credit risk. As under Basel I, off-balance sheet exposures are for capital purposes transformed into "assets" through the application of "credit conversion factors". The main changes compared to Basel I relate to the use of external credit ratings as the basis for determining the risk weights and the greater differentiation in the possible risk weights.
To give an example, risk weights for corporate exposures are now connected with their credit ratings as indicated in Table 1 (for illustrative purposes, ratings by Standard \& Poor's or S\&P are used).

Compared to Basel I, where all corporate exposures are weighted at $100 \%$, there is now a considerable differentiation in the risk weights. The weight for investment-grade firms has declined considerably (e.g. to $20 \%$ for AAA), whereas in the non-investment grade segment, a risk weight of $150 \%$ applies to firms rated below "BB-". Furthermore, unrated firms now obtain the same risk weight as that formerly obtained by all corporates under Basel I.

For claims on banks, the former distinction between institutions from OECD $(20 \%$ risk weight) and non-OECD countries (100\%) is no longer applied. Instead, two options are available to national supervisors. Under the first option, the risk weights for banks are derived from the ratings of the country in which the bank is incorporated. Under the second option, the risk weights are determined on the basis of the bank's own rating.

\begin{tabular}{|c|c|c|c|c|c|}
\hline \multicolumn{6}{|l|}{ (percentages) } \\
\hline Rating & AAA to AA- & $\mathrm{A}+$ to $\mathrm{A}-$ & $\mathrm{BBB}+$ to $\mathrm{BB}-$ & Below BB- & Unrated \\
\hline Risk weight & 20 & 50 & 100 & 150 & 100 \\
\hline
\end{tabular}


Retail exposures (75\% instead of $100 \%)$ and mortgage loans (35\% instead of $50 \%$ ) are treated more advantageously than under Basel I. Exposures to small businesses may under certain conditions also benefit from the preferred retail treatment.

The rating agencies, or external credit assessment institutions (ECAIs) as they are referred to in the New Framework, must obtain recognition from the banking supervisor before their ratings can be used by banks for determining risk weights. To get such recognition, an ECAI must satisfy each of the following six criteria:

1. Objectivity of the rating or credit risk assessment methodology.

2. Independence. The ECAI must be free from political or economic pressures, which could influence the analysis.

3. International access/transparency. The ECAI should offer its services to both domestic and foreign firms at similar terms.

4. Disclosure of material information. Includes the rating methodology, the definition of default, the time horizon, the meaning of each rating, the actual default rates experienced in each assessment category and the transition matrix. ${ }^{11}$

5. Sufficient resources for offering credit assessments of high quality.

6. Credibility of the credit assessments.

(b) Internal ratings-based approach

\section{Theoretical foundation}

The internal ratings-based (IRB) approach to credit risk is one of the most innovative elements of the New Framework because it allows banks themselves to determine certain key elements in the calculation of their capital requirements. Hence, the risk weights - and thus the capital charges - are determined through a combination of quantitative inputs provided either by banks or supervisory authorities, and risk weight functions specified by the BCBS. The new methodology is designed to be suitable for implementation by banks of different size, business structure and risk profile. Due to this characteristic, a standardised approach to modelling credit risk across all types of banks is used for supervisory purposes for the first time.

The IRB approach is closely linked to key results of academic work on credit risk modelling. ${ }^{12}$ Its theoretical basis is the asymptotic single risk factor (ASRF) model of credit risk. Here, the likelihood of a borrower being unable to repay his debt is derived from the distance between the value of its assets and the nominal amount of his debt. The value of the firm's assets is modelled as a variable which changes over time, in part as a result of the impact of random shocks. Default occurs when a borrower's assets are too low to cover its debt. The corresponding measure of credit risk within a certain time frame (commonly set at one year, also in Basel II) is the probability of default (PD).

The ASRF characteristic of the model implies that it does not take into account borrowerspecific idiosyncratic risks, i.e. risks that can be diversified away in the lending bank's loan portfolio. Instead, the model measures the marginal risk contribution of an exposure that it would add to an already well diversified portfolio. In this respect the IRB approach differs from models that some banks apply internally which measure a loan's risk contribution to a bank's actual portfolio, inclusive of a potential additional diversification effect achieved by adding an exposure to this specific borrower ("credit risk portfolio model"). The IRB approach therefore contains a deliberate simplification compared

11 The transition matrix provides a distribution of the likely changes in a borrower's credit quality (expressed by its rating) over a certain time period, usually fixed at one year.

12 Details on the theoretical background are given in Basel Committee on Banking (2005a) and Gordy (2003). 
with the most advanced techniques currently applied. This simplification allows for a model that is standardised and can be applied uniformly to banks of different sizes and portfolio compositions. It also avoids the particular uncertainties connected with the estimation of correlations between the risks of individual borrowers.

Under the IRB approach, the required minimum capital is based on the probability distribution of losses due to the default risk in a portfolio of loans or other financial instruments. The horizon of the risk assessment is set at one year. The IRB model further assumes a $99.9 \%$ confidence level. This means that once in a thousand years, the actual loss is expected to exceed the model's estimate.

\section{Designed to address unexpected losses}

As a result of the agreement reached by the BCBS in January 2004 with the "Madrid compromise", the IRB capital requirements now cover only unexpected losses whereas previously they were designed to cover both expected and unexpected losses. Unexpected losses are losses that occur above expected levels and this at a certain confidence level (99.9\%). Although capital requirements are designed to cover unexpected losses, banks have to cover their expected losses on an ongoing basis, e.g. through pricing, provisions and write-offs.

In the IRB framework, banks have to compare the stock of provisions they have made to cover loan losses with the expected losses based on the IRB parameters. Any shortfall should be deducted equally from core capital and supplementary capital ${ }^{13}$ and any excess will be eligible for inclusion in supplementary capital subject to a cap. The cap depends on the riskweighted assets and is currently set at $0.6 \%$.

Differentiated according to asset classes

Just like the standardised approach, the IRB approach distinguishes between asset classes (see Chart 3) to which different supervisory risk weight functions apply. Details on the capital requirements for standard corporate loans are provided below. The retail portfolio is of considerable importance because it also
13 Core capital or Tier 1 capital consists of own funds components of the highest quality, such as fully-paid capital and disclosed reserves from post-tax retained earnings. Supplementary capital or Tier 2/Tier 3 capital consists of own funds components of lower quality, such as certain types of subordinated debt.

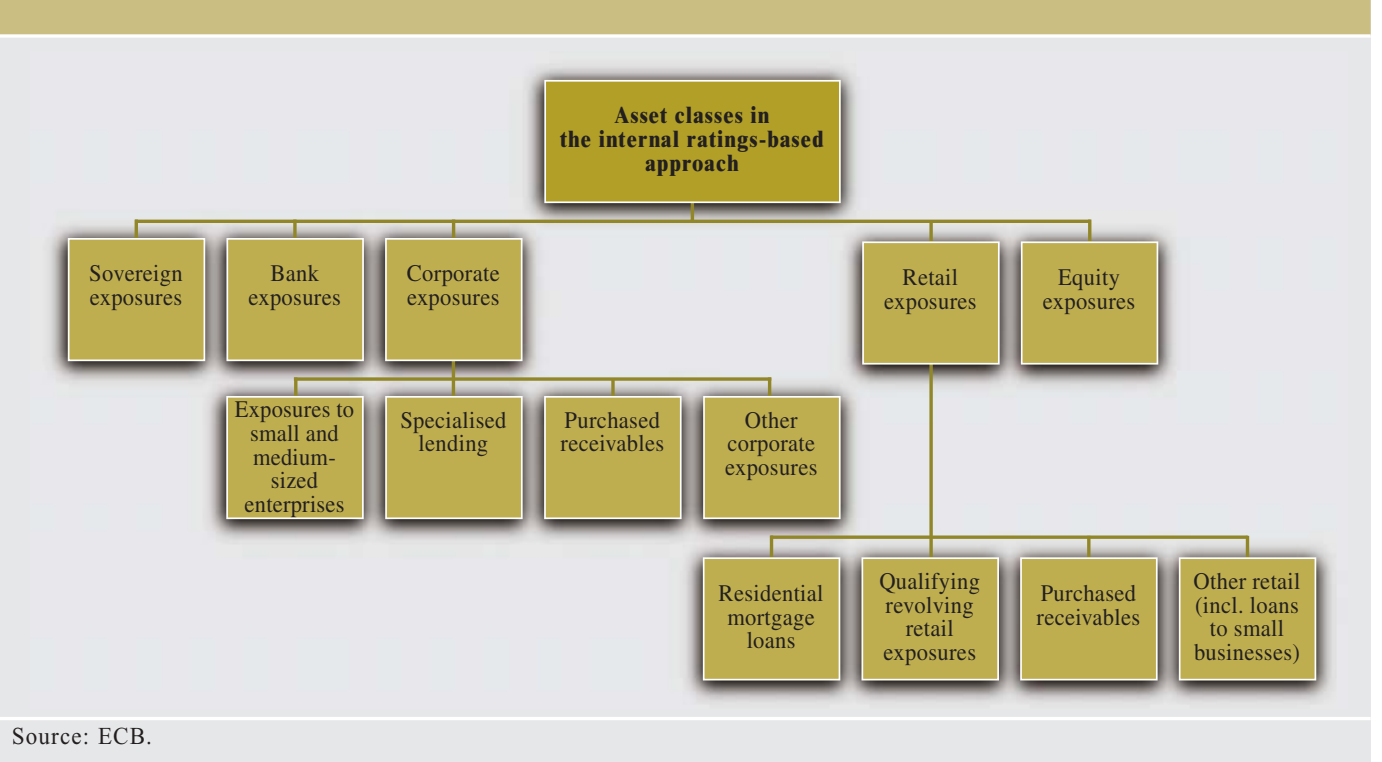


applies to a sizeable fraction of lending to small firms. Subject to certain conditions, the New Framework permits aggregate exposures to a single firm of up to $€ 1$ million to be treated under the IRB approach as retail exposures, which is advantageous compared to the treatment of other corporate lending. Even loans to other small and medium-sized enterprises (SMEs) that do not qualify as "retail" can benefit from a preferential treatment based on an adjustment relative to the firm's size under the standard corporate treatment. This reduction applies when the firm's total sales are between $€ 5$ million and $€ 50$ million and its impact declines in proportion to the sales. Economically, the firm size adjustment can be justified by the fact that default probabilities for smaller firms are observed to be less correlated with the overall state of the economy so that they contribute relatively less risk to a well diversified loan portfolio.

\section{Calculation method}

The calculation of capital requirements for a loan's default risk under Basel II requires four input parameters to the supervisory risk weight functions (see Chart 4):

1. Probability of default (PD): Estimate of the likelihood of the borrower defaulting on his obligations within one year.

2. Loss given default (LGD): Loss on the exposure following the borrower's default, commonly expressed as a percentage of the debt's original nominal value.

3. Exposure at default (EAD): Nominal value of the borrower's outstanding debt.

\section{Effective maturity of the loan (M).}

A "foundation" and an "advanced" version of the IRB approach is available, the difference in the two approaches being in the input variables for which the bank can use its own estimates. Both approaches rely on banks' PD estimates, but banks' internal estimates of LGD, EAD and $M$ can only be applied in the advanced IRB approach.

\section{Chart 4 Basic structure of the internal ratings-based approach}

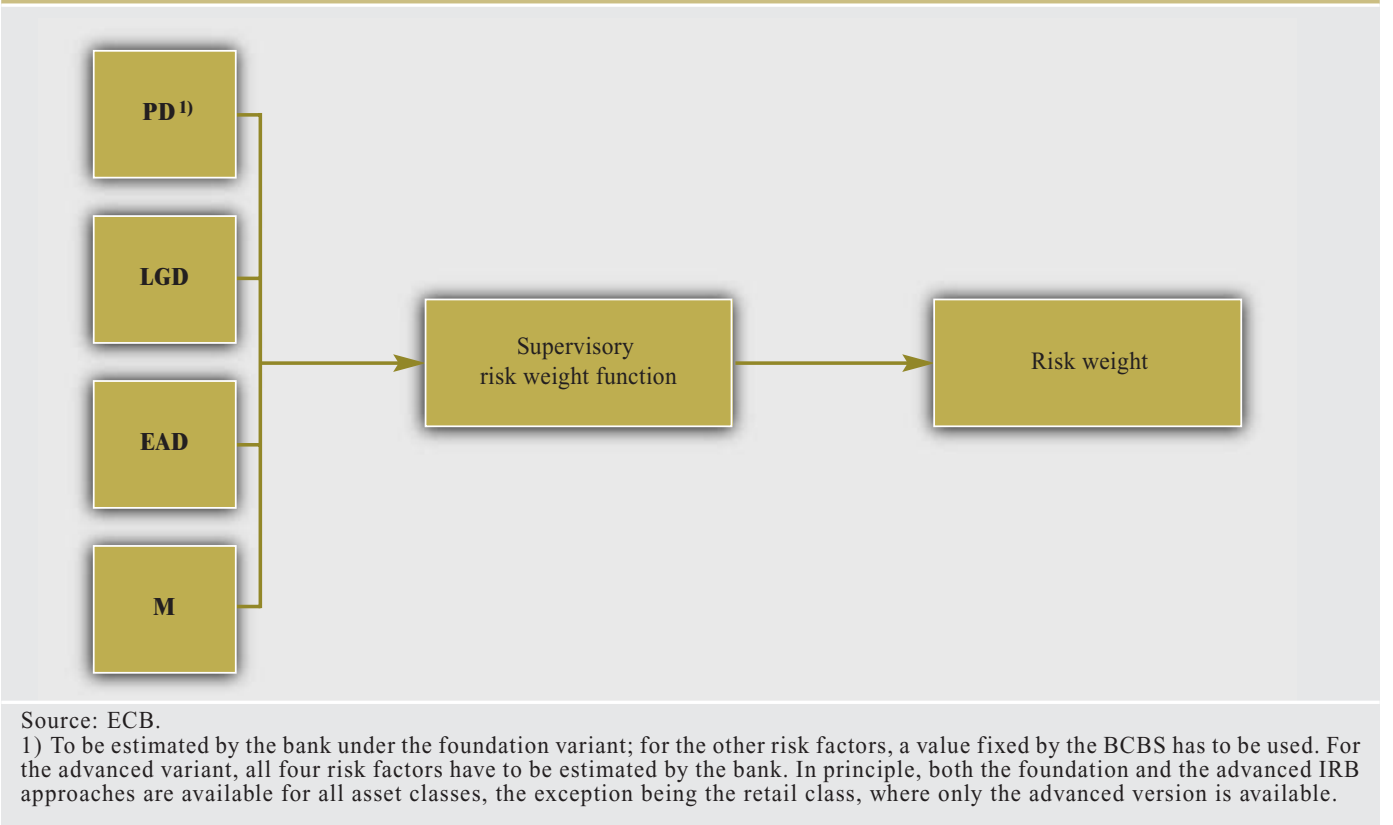


The resulting risk weights are plotted in Chart 5 with the PDs shown on the horizontal axis. As designed by the BCBS, the capital charge for retail portfolios is significantly below the charge for corporate loans. This difference is of considerable importance as it indicates that a large number of small borrowers, including small commercial undertakings, will benefit from a more favourable capital treatment than larger corporate borrowers.

A particular aim of the BCBS is to preserve overall capital neutrality compared to the current capital requirements, i.e. the capital required from an average bank should not differ markedly under the current Accord and Basel II. To this end, the BCBS had introduced into the IRB formula a multiplier which is currently set at 1.06 (not reflected in Chart 5). This value is based on the studies that the BCBS has performed so far on the overall impact of the new requirements. With future assessments of the quantitative impact of the new capital rules, the issue of capital neutrality may have to be readdressed. This multiplier provides then for a simple way to adjust the overall level of capital required from IRB banks.

\section{Practical implementation}

The use of the IRB approach is subject to an explicit supervisory approval, which depends on meeting certain minimum requirements from the outset and on an ongoing basis. These requirements are aimed at the IRB system providing an adequate assessment of the bank's exposures, a meaningful differentiation of risk and a reasonably good estimate of risk. For example, a qualifying IRB system is required to have two separate dimensions, the risk of borrower default and transaction-specific factors (e.g. collateral, seniority, product type). The IRB approach must also be consistent with the internal use by the bank of the estimates it produces ("use test").

In the practical implementation of the IRB system, validation (the assessment of the soundness of the different system elements) will be important. In this context, the Accord

\section{Chart 5 IRB risk weights across asset classes}

(percentages

corporate, sovereign and banks exposures exposure to small and medium size entities

- - retail exposure: residential mortgage loans

_ retail exposure: revolving credits other retail exposures

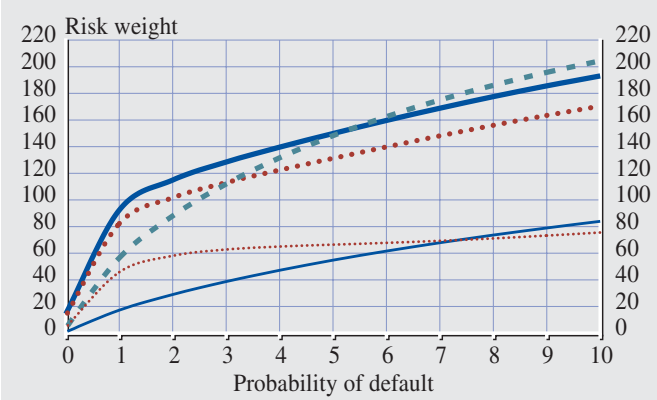

Source: ECB

Note: Standard assumptions about the risk factors other than $\mathrm{PD}$, are made. Risk weights are calibrated to cover only unexpected losses, which have to be met via capital requirements.

Implementation Group (AIG) of the BCBS has outlined a number of principles. ${ }^{14}$ First, validation is interpreted as an assessment of the predictive ability of a bank's risk estimates and the use of ratings in the credit process. In addition, the bank has primary responsibility for validation. Furthermore, validation of the IRB approaches should encompass both quantitative and qualitative elements. Finally, validation processes and outcomes should be subject to an independent review.

\section{(c) Asset securitisation}

Securitisation is one of the most rapidly growing activities of major banks. Banks increasingly apply it to pools of loans on their balance sheets. In parallel, other credit instruments such as corporate bonds are increasingly used as underlying assets for securitisation transactions. With the explicit treatment of securitisation, Basel II provides for an internationally harmonised standard for the supervisory treatment of such transactions. At the same time, by making the capital requirements depend on the risk in the

14 Basel Committee on Banking Supervision (2005c). 
securitisation positions, Basel II aims at reducing the scope for capital arbitrage, a key drawback of the current framework and apparently an important securitisation driver.

Pillar I contains detailed rules for the supervisory treatment of securitisation, which cover the two roles a bank can play in a securitisation transaction, namely as originator and investor. In the first case, the bank securitises its own assets; in the second case, it buys and holds tranches of securitisations. Basel II deals with traditional transactions, e.g. the sale of loans through asset backed securities, as well as synthetic securitisations, such as the transfer of credit risk through credit derivatives without selling the loans.

Just as for credit risk, a number of approaches of different complexity are introduced to deal with the wide variety in instruments and degree of sophistication of the bank. Also here, a standardised and an IRB approach are available. The structure of the standardised approach for securitisation exposures is similar to the standardised approach for credit risk, although tranches that carry a higher risk or are unrated are dealt with more conservatively (higher risk weight or capital deduction).

Banks which were given supervisory approval to use the IRB approach for the type of underlying exposures securitised must also apply the IRB methodology to securitisation. However, instead of a foundation and advanced approach, there are now three ways of calculating capital requirements: the (external) ratings-based approach, the supervisory formula approach and the internal assessment approach. The first is similar to the standardised approach, although a greater risk differentiation is provided for. The next two approaches apply to unrated exposures, and the third only to the specific case of exposures resulting from ABCP (asset backed commercial paper) programmes.

\section{(d) Credit risk mitigation}

Compared with the current Capital Accord, the New Framework contains a wider range of credit risk mitigation techniques that may receive recognition in the form of lower capital requirements, subject to prudent eligibility standards. For credit risk mitigation in the form of guarantees and credit derivatives, the borrower's risk weight is replaced by that of the protection provider. This "substitution approach" was recently modified by the BCBS to take account of the pair-wise correlation of the borrower and protection provider's default probabilities. ${ }^{15}$

For collateralised exposures, the Framework comprises a range of methodologies that are of different degrees of sophistication. In general, the more sophisticated the methodology and the more stringent the application conditions, the wider the range of eligible collateral. Compared to Basel I, the range of eligible collateral has also been expanded.

Banks using the standardised approach can apply the "simple method" for financial collateral under which the risk weight of the borrower is replaced by the risk weight that would apply to the collateral if it were the exposure. Under both the standardised and the foundation IRB approaches, there is also a "comprehensive method" for financial collateral that foresees that the exposure amount under the standardised approach, or the supervisory LGD under the foundation IRB, is reduced to reflect the adjusted value of the collateral. In adjusting the collateral value, banks have to take account of the volatility of its market value. A specific feature of the foundation IRB is the presence of a supervisory method for the recognition of certain physical collateral.

For banks using the advanced IRB, the range of admissible collateral is unbounded as long as the bank can demonstrate that it has good estimates for the collateral value in the 
situation when the borrower has defaulted. While under the standardised approach there is in principle no recognition of physical collateral, real estate collateral is an exception. Also under the foundation IRB approach, there are particular conditions that need to be observed for this kind of collateral, as discussed in greater detail in Section 6.

\subsubsection{CAPITAL REQUIREMENTS FOR OPERATIONAL RISK}

Operational risk has so far not been subject to capital requirements. However, this does not imply that adding this new component to regulatory capital leads for an average bank to higher overall requirements. Rather, the additional requirement for operational risk corresponds on average to lower capital requirements for credit risk compared with the current rules so that the BCBS goal of capital neutrality can on balance be reached. For operational risk, three options of different levels of sophistication are introduced.

The two most simple options are based on an indicator, namely gross income, which serves as a rough proxy for the size and the degree of risk of the operations. For this purpose, gross income is defined as the sum of net interest income and net non-interest income. Fees paid to outsourcing providers are not deducted from the income because it was considered that outsourcing is not a perfect mitigant for operational risk and should therefore not lead to lower capital requirements. Gross income is also adjusted for a number of items that are considered irregular and is in addition smoothed by using a three-year average, excluding negative annual figures. This indicator, multiplied with a supervisory factor, delivers the capital requirement.

Under the basic indicator approach, the supervisory factor (called "alpha") is applied to the total gross income. Under the standardised approach, the gross income is split out over eight different business lines, namely corporate finance, trading and sales, retail banking, commercial banking, payment and settlement, agency services, asset management, and retail brokerage. To each business line a different supervisory factor (called "beta") is applied, reflecting the relative risk of the business line according to the BCBS' expert judgment. The average beta equals the alpha so that clear incentives to adopt the standardised rather than the basic indicator approach are only present for those banks that derive most of their gross income from business lines with low betas, such as retail banking. Banks that want to use the standardised approach have to implement a risk management for operational risk that conforms to a number of qualitative minimum requirements; such requirements are not mandatory for banks using the basic indicator approach.

In contrast to the case of the IRB as the most advanced approach for credit risk, the BCBS does not resort to a single modelling technique for operational risk. Rather, the most advanced option for determining regulatory capital for operational risk consists of a class of approaches referred to as the advanced measurement approaches (AMA). Under the AMA, the regulatory capital requirement is calculated on the basis of banks' internal operational risk measurement systems. These have to take account not only of actual internal and external loss data, but also of scenario analyses and factors relating to the banks' business environment and internal controls. Furthermore, the model has to achieve a statistical soundness standard comparable to that of the IRB approach, where capital charges are based upon a one-year time horizon and a 99.9\% confidence level, as described above. Subject to compliance with these model properties, banks are free to develop their own approach. This freedom is explained by the fact that, until now, no reliable candidate for a standard operational risk model has been identified.

In addition to the soundness standards for the model itself, banks that request approval from their supervisors for their AMA have to comply 
with minimum requirements on their operational risk management that are more demanding than for the standardised approach. By taking into account banks' business environment and internal controls, banks under the AMA are in principle able to mitigate their operational risk capital charge by improving their operational risk management, for instance by introducing enhanced controls into the business process. However, many open methodological questions still remain with respect to how this can be done in a sound and practical manner. Banks are also allowed to recognise insurance as a risk mitigant for up to $20 \%$ of their AMA capital requirements; the condition is that their insurance contracts and providers meet certain eligibility standards.

In the context of operational risk capital requirements, the study by De Fontnouvelle et al. (2004) is of considerable importance. Using loss data from a number of internationally active banks, the authors find that loss data by event types are quite similar across institutions. They also show that their results are consistent with economic capital numbers disclosed by some large banks, and with the results of studies modelling losses using publicly available "external" loss data.

\subsection{PILLAR II - SUPERVISORY REVIEW PROCESS}

Under Pillar II, banks assess their capital adequacy on the basis of own internal risk management methodology and supervisors analyse whether a specific bank's capital adequacy assessment is in line with its overall risk profile and business strategies. A consistent application of supervisory practices across countries is of great importance to avoid any undue compliance burden and to ensure a level playing-field. This is particularly true if banks belonging to the same group aim to make use of group-wide risk management but face different expectations from their respective national supervisory authorities. Convergence and cooperation in supervisory practices may constitute a way to alleviate this concern. The extended role for the authority that exercises consolidated supervision, as provided for in the proposed EU rules, deserves particular attention in this regard (see Section 5).

Under the supervisory review process, the question will also be addressed whether the bank should hold additional capital against risks that are not, or not fully, covered in Pillar I, and this may involve supervisory action when this is indeed the case. An active role for supervisory authorities will give banks incentives to continuously improve their risk management models and systems. Relative to the present situation, Pillar II requires supervisors to apply considerably more discretion in their assessment of capital adequacy in individual banks.

The supervisory review process relies on four principles:

1. Banks should have a process for assessing their overall capital adequacy in relation to their risk profile and a strategy for maintaining capital levels.

2. Supervisors should review and evaluate banks' internal capital adequacy assessments and strategies, as well as their ability to monitor and ensure compliance with regulatory capital ratios. If they are not satisfied with the result of this process, supervisors should take appropriate action.

3. Supervisors should expect banks to operate above the minimum regulatory capital ratios and should have the ability to require banks to hold capital in excess of the minimum.

4. Supervisors should seek to intervene at an early stage to prevent capital from falling below the minimum levels required to support the risk characteristics of a bank and should require rapid remedial action if capital is not maintained or restored.

The BCBS has outlined some important issues to which both banks and supervisors should 
devote attention in the supervisory review process. These issues also include risk categories which are not directly addressed under Pillar I, such as interest rate risk in the banking book ${ }^{16}$ and credit concentration risk.

Interest rate risk in the banking book has been given specific attention because it is seen by regulators as a material risk in the banking system. Although the market risk amendment of 1996 introduced interest rate risk as a separate category, it was aimed at the exposures in the trading book. Hence, the 1996 modification focused on the risk of losses arising from, for example, bond portfolios or other categories of fixed-income instruments held for trading. The BCBS acknowledged this gap in the treatment of losses coming from sharp interest rate changes. While it did not add a separate capital requirement, wording has been included under Pillar II that requires supervisors to identify those banks as outliers that would experience a loss amounting to more than $20 \%$ of their capital from a simulated standardised interest rate shock. Supervisory authorities must take measures to address the situation of such outlier banks.

As regards the treatment of credit concentration risk, there are two complementary motivations. First, several banking crises have been clearly linked to material risk concentrations in bank portfolios. Second, the ASRF model, which is the basis for the IRB approach, relies on two assumptions about a significant diversification in bank portfolios. First, the ASRF assumes that no borrower accounts for more than a very small share of total portfolio exposure. Second, it assumes that banks are well diversified across geographical areas and industrial sectors within a large economy. Both assumptions may be valid for the majority of exposures of some of the larger banks, but in the EU, the IRB approach is likely to also be applied to smaller banks, where concentration of exposure to individual borrowers or certain sectors may be more substantial. In this context, it should be recalled that the rules on large exposures in the
Codified Banking Directive (2000/12/EC) already serve to limit single-name concentration risk. Theoretical analysis has shown that a ratings-based approach to setting capital requirements needs the two aforementioned assumptions, at least implicitly. Therefore, the concentration problem cannot be addressed merely by modifications to the IRB risk-weights. Hence, under Pillar II, supervisors will analyse potential risk concentrations and may also potentially develop appropriate Pillar II capital buffers against such risk concentrations.

\subsection{PILLAR III - MARKET DISCIPLINE}

Under Pillar III, banks will be required to publish information focused on the key parameters of their business profile, risk exposure and risk management. Such disclosures are seen as a precondition for the effective working of market discipline on banks. For banking groups, the requirements apply to the top consolidated level of the banking group.

Both qualitative and quantitative information must be disclosed. Hence, disclosure is required on the structure and adequacy of capital, and should therefore include details on the core capital. It is envisaged that credit, market and operational risk are addressed separately. For the disclosure of credit risk, it is also planned to publish data on the portfolio structure, the major types of credit exposure, the geographical and sectoral distribution and impaired loans. In addition, information on credit risk mitigation techniques and asset securitisation has to be provided. Banks will be required to outline some details on their use of IRB approaches, which represent a major component of the New Framework. Regarding market risk, banks have to summarise the key

16 The banking book is the bank portfolio which consists of financial instruments that are not held for trading. The trading book is the bank portfolio that consists of financial instruments that are held for short-term trading purposes, i.e. they are held intentionally for short-term resale and/or with the intent of benefiting from short-term price movements or to lock in arbitrage profits 
details of their internal models where applicable and to describe their use of stress testing and back testing. Disclosure requirements further cover the management of and the compliance with requirements on operational risk. Finally, the New Framework requires that information on equity holdings and interest rate risk in the banking book to be published.

\section{THE NEW FRAMEWORK IN THE EU}

\section{I LEGAL AND INSTITUTIONAL SETTING}

One month after the BCBS published its document on the New Framework, the European Commission released its own proposals on new capital requirements for banks and investment firms in the EU. ${ }^{17}$ The proposals reflected to a large extent Basel II, but were at the same time tailored to the specific features of the EU market. The Commission's initiative is part of the wider Financial Services Action Plan (FSAP) launched in 1999. The FSAP outlined a number of policy objectives and measures to improve the Single Market for financial services. One of its objectives was to ensure financial stability by keeping pace with state-of-the-art prudential rules and supervision, in particular in the area of banks' solvency requirements. The Single Market is an important factor that explains why in some cases the proposed EU rules go further than the Basel rules.

Thereafter, the Commission's proposals have been subject to scrutiny by the European Parliament and the Council and to tripartite negotiations with the Commission. These negotiations resulted in a package of almost 600 amendments, subject to which both the Parliament and Council approved the proposals in September and October 2005. In this way, they cleared the way for the new capital requirements to enter into force in the $\mathrm{EU}$ as scheduled by the BCBS.
Although there are a large number of amendments, they leave the content and thrust of the Commission's proposals intact. The amendments introduce the trading book review and double default treatment as released by the BCBS in July 2005, reduce the number of national discretions, make some minor technical corrections and take account of several specific concerns relating to Member States' national markets. Finally, the amendments also provide a preliminary solution to the long debated issue of institutional balance in the "comitology" procedure as part of the Lamfalussy approach, which is discussed in more detail below.

An important distinguishing feature of the implementation of the Basel rules in the European Union is the legal nature of the capital adequacy framework. While the Basel II Framework takes the form of an accord or agreement amongst national banking supervisors represented in the BCBS - thus implementation remains in principle voluntary - in the EU, the framework is legislative and binding in all EU Member States. The Basel II Framework will be transposed into EU legislation by means of the Capital Requirements Directive (CRD). Technically, this has been done via a recasting of the existing Codified Banking Directive or CBD (2000/12/EC) and the Capital Adequacy Directive or CAD (93/6/EEC). The re-casting technique, established by the interinstitutional agreement 2002/C77/01 of 28 November 2002, allows the incorporation in current legislative texts of both amended and unchanged provisions.

Another significant element is the regulatory and supervisory setting that is now in place in the EU as a result of the "Lamfalussy" approach (see Box 2). This approach was initially applied to the securities sector ${ }^{18}$ but

17 European Commission Services (2004).

18 The Lamfalussy approach was set out by the Committee of Wise Men on the Regulation of European Securities Markets, chaired by Baron Alexandre Lamfalussy, in its "Final Report" dated 15 February 2001. 
was later extended to all financial sectors, including banking. It was introduced with the aim of improving the speed and flexibility of the rulemaking process, so that regulation can better keep up with developments in financial markets.

\section{Box 2}

\section{THE LAMFALUSSY APPROACH}

\section{Level 1}

Proposal for Community legislation advanced by the European Commission and adopted under the co-decision procedure by the Council and the European Parliament. The legislation takes the form of directives or regulations. It should be limited to framework principles and define the powers for the Commission to implement the necessary technical rules.

\section{Level 2}

The European Commission enacts legislation containing the technical details for the framework principles approved at Level 1. This requires the intervention of a regulatory committee under the "comitology procedure". These regulatory committees are chaired by the Commission and composed of high-level representatives from Member States. The ECB has observer status in the banking, securities and financial conglomerates committees.

The "Level 2" regulatory committees

Banking

Securities and investment funds

Insurance and pension funds

Financial conglomerates
European Banking Committee (EBC)

European Securities Committee (ESC)

European Insurance and Occupational Pensions Committee (EIOPC)

European Financial Conglomerates Committee (EFCC)

\section{Level 3}

Level 3 committees are entrusted with the task of facilitating the day-to-day implementation of Community law with the goal of converging both supervisory practices and the application of Community legislation, and enhancing supervisory cooperation. Guidelines, interpretative recommendations, common standards or best practices may be issued, but these are not legally binding and implementation remains voluntary. Level 3 committees also assist the Commission in drafting the more technical provisions of the legislation enacted at Level 2. The supervisory committees are composed of high-level representatives from the competent national supervisory authorities.

The "Level 3" supervisory committees

Banking

Securities and investment funds

Insurance and pension funds

Financial conglomerates
Committee of European Banking Supervisors (CEBS) Committee of European Securities Regulators (CESR) Committee of European Insurance and Occupational Pensions Supervisors (CEIOPS)

At present, there is no Level 3 committee

1 The procedure whereby the Commission is assisted by a Committee comprising representatives from Member States in the adoption of implementing measures for Community legislation. Council Decision 1999/468/EC of 28 June 1999 laying down the procedures for the exercise of implementing powers conferred on the Commission specifies the types of comitology procedures governing the adoption of implementing measures. 
Level 4

The European Commission is responsible for ensuring that Member States' national law complies with Community law and, if needed, to take enforcement action. Legal action against Member States can be taken before the European Court of Justice. Strengthening enforcement is underpinned by enhanced cooperation between Member States, the regulatory bodies and the private sector.

The increased flexibility of the legislative process envisaged by the Lamfalussy approach is reflected in the CRD transposing the capital requirements into EU law. Whereas amendments to the main principles still have to be made via co-decision, amendments to the more technical provisions can be introduced via the more flexible and faster "comitology" procedure. However, the CRD is not a pure "Lamfalussy directive" as it combines both framework principles and technical implementation rules in the same legal instrument.

The issue of "comitology" and the institutional balance between Parliament, Commission and Council was long debated given that the current procedure does not grant the Parliament the right to "call back" the "comitology" powers of the Commission, although such a right was intended to be introduced as part of the Constitutional Treaty. A last minute compromise between Commission, Council and Parliament as part of the above-mentioned amendments means that the current comitology system - which provides no formal "call-back" right for Parliament - can be used to implement and update the Directives for a maximum of two years or until 1 April 2008 at the latest. After this period, aforementioned powers can be renewed only with the agreement of the three institutions. This timeframe should allow for reflection on a possible recalibration as scheduled by the BCBS for Spring 2006.

The implementation of the New Framework represented in principle a "window of opportunity" to structure the new rules along the lines of what had been introduced for the securities sector. This would have entailed a clear distinction between framework principles (Level 1 acts) and technical implementation rules (Level 2 acts), with the adoption of regulations for the latter, whenever appropriate. In general, recourse to regulations would reinforce convergent implementation across the EU, given that they are directly applicable in all Member States, as opposed to directives, which need to be transposed into national law. This in turn would facilitate compliance by cross-border groups and contribute to promoting a level playing-field and further integration. This opportunity was not exploited and hence, the current legal framework should be viewed as a first step in a longer term process where the ultimate goal would be to arrive at a uniform and directly applicable set of European rules for financial institutions.

Regulatory convergence and a consistent implementation of rules across Member States are important to ensure a level playing-field in the Single Market. However, the CRD still includes several national discretions, meaning that the scope for potential divergent national implementation is considerable. In addition, the use of terms that are not clearly defined provides national authorities with considerable leeway, which may also result in significantly different interpretations. In this respect, the work by the Level 3 banking committee - the CEBS - is crucial. The CEBS has given priority to the identification and reduction of national options. The progress achieved thus far by the CEBS is reflected in the final CRD text and must be acknowledged, while the pursuit of more work in this field should be strongly encouraged. As the EU financial systems become increasingly more integrated, some of the remaining national 
discretions may become obsolete over time, necessitating further revisions.

Furthermore, in its work on supervisory convergence regarding the new capital rules, the CEBS is focusing on a number of important areas. ${ }^{19}$ Foremost is the development of a common reporting framework for the new solvency ratio, which is especially important for cross-border banking groups that are presently confronted with a variety of national reporting schemes. The CEBS is also working on guidance for the supervisory review process, which comprises the bank's internal capital adequacy process and the supervisory review and evaluation process. As regards the standardised approach, a common approach is underway for the recognition of external credit assessment institutions (ECAIs), as well as for developing the criteria to transform ("map") ratings into risk weights. For the advanced calculation methods, a common approach to validation principles is being defined. Another important task is to foster cooperation between home and host authorities. Finally, the CRD not only provides for disclosure by banks but also by supervisors, for which the CEBS is establishing a common framework.

\subsection{SPECIFIC FEATURES OF EU IMPLEMENTATION}

The implementation of the new capital rules in Europe will not fully mirror the Basel II Framework; rather the EU rules have been adapted in order to reflect the specific Single Market context, which encompasses such features as the single banking licence, home country control and minimum harmonisation of prudential requirements. The main specificities of the European setting that have been taken into account when developing the EU rules are presented below.

\section{(a) Scope of application}

One of the main diverging aspects concerns the scope of application of the rules. Just like Basel I, the Basel II Framework is envisaged to apply only to internationally active banks. The
European implementation of the capital requirements, by contrast, will in principle apply to all banks and investment firms,${ }^{20}$ independent of their size or the geographical scope of their activity. Financial institutions dealing in the same activity or providing similar services will therefore be subject to the same capital requirements, thus ensuring a level playing-field within the EU. In this respect, it should be recalled that following the $\mathrm{CAD}$, banks and investment firms in the EU are already subject to the same capital rules. This similar treatment is rooted in the fact that the $\mathrm{CBD}$ allows the universal banking model, i.e. the combination of banking and securities activities in the same legal entity or within the same financial group.

Another difference in the scope of application is the level at which the new rules apply. The Basel II rules apply to internationally active banks at every layer of the banking group on a (sub)consolidated basis. No general explicit capital requirements are formulated for individual banks, but when an entity of the group itself qualifies as an internationally active bank, the Basel II capital requirements must also be met by this entity. The EU rules, by contrast, apply in principle both on a consolidated and an individual (solo) basis. However, subject to certain conditions, the CRD contains the possibility to waive the solo requirements on (only) domestic subsidiaries. The conditions for this waiver are aimed at ensuring that the parent guarantees the commitments of the subsidiary that has been exempted from the solo capital requirements.

\section{(b) Range of available approaches}

The full spectrum of approaches for the calculation of capital requirements as envisaged by the Basel II Framework, from the simple methods to those based on internal

19 This is reflected in the different Consultation Papers (CP) released by the CEBS. See in particular the CP3 (supervisory review process), CP4 (solvency reporting framework), CP5 (supervisory disclosure), CP7 (recognition of ECAIs), CP9 (supervisory cooperation) and CP10 (validation of advanced calculation methods)

20 Investment firms are firms authorised under the Markets in Financial Instruments Directive (MiFID), 2004/39/EC.

\section{THE NEW FRAMEWORK \\ IN THE EU}


models, will be available in the EU. The application of the New Framework in the EU to all banks and investment firms, irrespective of their level of complexity or sophistication, indeed requires the full spectrum of approaches to be available to all institutions. In this context, it should be noted that, in the US, the application of Basel II will only encompass the most advanced methods (see Box 3).

The comprehensive scope of application in the EU was also the basis for the development of rules on "permanent partial use". In the context of credit risk, partial use refers to the possibility of using the simpler standardised approach for certain exposure classes, while applying the more sophisticated IRB approaches for the remaining classes. Under Basel II, a bank using the IRB for any exposure may only permanently apply the standardised approach for so-called non-material exposure classes and business lines. All other exposures have to be treated under the IRB within a time frame agreed with the respective supervisor upfront ("roll out" plan). This rule aims to limit the potential for "cherry-picking" between approaches with different risk sensitivities.

For small EU banks, it may be particularly hard, or even impossible, to roll out the IRB approach to certain exposure classes where they have a very limited number of counterparties. Nevertheless, the exposure to these counterparties may still be material in relation to the bank's overall exposures. For this reason, there is the possibility for exposures to banks, investment firms, sovereigns and certain other public sector bodies to qualify for a permanent partial use. Such exposures could then remain on the standardised approach, independent of their materiality, while the bank otherwise uses the IRB approach.

The broad application in the EU of the capital requirements framework to institutions that range from very sophisticated internationally active banks to less complex investment firms, together with the potentially burdensome overall impact of the new rules on certain investment firms, requires that the prudential standards be adapted. Therefore, investment firms falling within certain categories may be exempted by the competent authorities from calculating capital requirements for operational risk. Where this exemption is used, the currently used "expenditure-based" capital charge, that is otherwise abolished, will be retained. Under this approach, investment firms are required to hold minimum capital in relation to their overhead costs.

\section{Box 3}

\section{IMPLEMENTATION OF BASEL II IN THE US AND ITS IMPLICATIONS FOR EU BANKS}

The US authorities decided to confine the spectrum of approaches available in the Basel II Framework. ${ }^{1}$ Large internationally active banks (consolidated assets over USD 250 billion and foreign exposure of at least USD 10 billion), including subsidiaries of foreign banks, will be required to use only the advanced methodologies to calculate capital requirements. These methods include the advanced IRB approach for credit risk and the AMA for operational risk. Approximately ten banks fall into this category. In addition, other banks that meet the requirements for the use of the advanced approaches will be allowed to opt into Basel II. This will be the case for approximately another ten banks. Overall, the banks which are expected to apply Basel II are those that are active in cross-border banking. They account for approximately $99 \%$ of the foreign assets held by the top fifty US banking organisations and for about two-thirds of the assets of US banks. The remaining banks (approximately 6,500) in the

1 Federal Reserve Board et al. (2003). 
US and subsidiaries of foreign banks that do not meet the criteria to adopt Basel II will remain under the current Basel I rules. ${ }^{2}$

The implementation of Basel II in the US may have implications for EU banks operating in the US, especially those with a significant presence (see chart for some examples). These banks may be required to operate under rules that differ from those applying to the rest of the banking group, in particular the parent company in the respective home country. This can be costly and inefficient and potentially raises negative competitive effects for European banks. A US subsidiary of a foreign bank has to comply with US rules, which will entail the need for these subsidiaries to either meet the prerequisites in order to apply the advanced approaches of Basel II or to remain under the current Basel I based rules. Hence, subsidiaries which would have targeted the foundation IRB will continue to apply the Basel I rules, irrespective of whether or not the rest of the banking group applies these approaches on a consolidated basis.

The US authorities have publicly conveyed that they would be prepared to explore the possibility of allowing foreign subsidiaries to use conservative estimates for a transition period. ${ }^{3}$ However, further work to develop concrete proposals still needs to be pursued. In this context, the work of the BCBS' Accord Implementation Group (AIG) in maintaining a level playing-field across countries and in achieving an acceptable level of consistency in the implementation of Basel II is of the utmost importance.

More recently, the results of the fourth quantitative impact study (QIS4) have shown a much higher than expected capital reduction (of around $15 \%$ on aggregate and by more than $26 \%$ in more than half of the participating banks) vis-à-vis the current level of the 26 large US financial institutions replying to the QIS4, and also a very wide dispersion across banks (ranging from a decrease of $47 \%$ to an increase of $56 \%){ }^{4}$

These results have prompted the US authorities to delay the scheduled publication of the Notice of Proposed Rulemaking (NPR). They now plan to make the US Basel II proposal available in the first quarter of 2006 and to introduce additional prudential safeguards to address the concerns resulting from the QIS4. In particular, a one-year delay in the implementation will be proposed. Further, the capital floors tied to the current Basel I rules will extend to 2011, after which they will be reconsidered on an institution-by-institution basis. ${ }^{5}$ Given the significant implications that the decisions by the US authorities may have in maintaining a level playing-field internationally, this is an issue that will have to be closely monitored in the EU.

2 These rules will be revised somewhat and made more risk-sensitive. This regime is sometimes called "Basel IA".

3 Ferguson (2003)

4 Schmidt Bies (2005) and Powell (2005).

5 Federal Reserve Board et al. (2005) 
(c) External credit assessment institutions External credit assessment institutions (ECAIs) play an important role in the New Framework as their assessments (ratings) will be used for the calculation of the capital charge for credit risk under the standardised approach. In order to obtain regulatory recognition for capital purposes, ECAIs need to comply with minimum requirements. ${ }^{21} \mathrm{~A}$ high degree of consistency of Member States' practices regarding the recognition of ECAIs will be indispensable. In this way, comparability of ratings and a level playing-field for ECAIs can be ensured and the potential risks for regulatory arbitrage reduced. Moreover, supervisory co-operation will be crucial to reduce the compliance costs for those ECAIs that seek recognition in more than one Member State.

The possibility of applying the principle of mutual recognition to ECAIs should in that respect be very helpful. However, whilst the CRD only includes an option for mutual recognition, one could argue that this should be the general rule for ECAIs within the EU. If a competent authority in a Member State assesses an ECAI as complying with the eligibility criteria, this evaluation could then be used automatically by the competent authorities in other Member States without conducting any further assessment. The same rationale applies when a competent authority has developed a mapping for an ECAI's ratings on supervisory risk weights. Competent authorities in other Member States could then accept and use this mapping without determining their own process.

The recognition of ECAIs for solvency purposes is expected to influence the availability of external ratings. This, in turn, will have an impact on the assessment of the eligibility of collateral for the credit operations of the Eurosystem, which comprises the ECB and the twelve national central banks of the euro area, given the need for marketable debt instruments to have a high credit standing to be included in the list of collateral accepted.
Although the Eurosystem uses its own assessment criteria, the eligibility criteria and the process of recognition for supervisory purposes will influence the quality of the ratings and the level playing-field in the ratings' market.

In this context, it is important to achieve a prudent and fair approach to supervisors' assessment of ECAIs, especially to avoid creating entry barriers for new market players. For the latter, the focus should therefore be on the evaluation of the robustness and soundness of assessment methodologies rather than on, for example, market acceptance or "track record".

\section{(d) Supervisory disclosure}

The EU capital framework introduces specific disclosure requirements for the Member States' competent authorities. ${ }^{22}$ These requirements, which should be distinguished from the Pillar III requirements that target banks' disclosures, were introduced with the aim of enhancing supervisory convergence and transparency. This innovative aspect, not mirrored in the Basel II Framework, is expected to contribute to the maintenance of a level playing-field and the fostering of financial integration. The disclosures encompass a minimum set of requirements that range from the publication of the legal texts and rules to the exercise of certain discretionary measures or the choice of certain options available in the new rules. With regard to the exercise of effective supervision, both the general criteria and the methodologies used during examinations of the supervised entities covered under the supervisory review process should be made publicly available. Finally, aggregate statistical data on some key implementation aspects have to be published as well.

\section{(e) Private equity and venture capital}

In striving to improve the competitive position of the European economy, concerns were raised that the new capital rules would have a negative

21 On this, see also the CP7 of the CEBS

22 On this, see also the CP5 of the CEBS. 
impact on the private equity and venture capital industry, which is seen as a key driver for economic growth. Banks in the EU play a crucial role as the main source for this kind of financing. Banks provide on average approximately a quarter of the total funds raised, although there are important differences across Member States (see Chart 6).

The concern that the increase in risk weights for equity investments may lead to a significant reduction in the bank financing of investments in private equity and venture capital triggered additional research. The impact study carried out in the EU on the New Framework raised the issue that for investments in venture capital through a diversified venture capital fund, the risk weightings under the IRB approach proposed by the European Commission in its Third Consultative Proposals (CP3) were rather high (PricewaterhouseCoopers, 2004). This report recommended that the treatment of equity exposures should consider the profile of the investments, taking into account the degree of diversification. This recommendation was incorporated in the CRD. For investments in private equity firms that constitute sufficiently diversified portfolios, the risk weights assigned under the IRB rules are now lower than under the Basel II Framework. For example, under the "simple risk weight approach" for equity exposures, the capital charge under the EU rules may in certain instances be approximately $24 \%$ lower than under Basel II.

\section{(f) Financing of small and medium-sized enterprises}

Small and medium-sized enterprises (SMEs) play an important role in fostering economic growth and entrepreneurship, and often act as sub-contractors to larger firms. They use relatively more bank financing than larger enterprises and many of them have credit lines with only one bank. SMEs represent more than $99 \%$ of all EU enterprises by number and about $70 \%$ of total employment (European Commission, 2003b). These figures are comparable to the situation in the US and

\section{Chart 6 Share of banks in new funds raised for private equity}

3 THE NEW FRAMEWORK

IN THE EU
Japan, although in the US, SMEs account for a much lower share of employment.

In the context of the new capital rules, there have been concerns that quantitative rating methods such as the IRB approach might put more emphasis on financial ratios than on qualitative factors such as the entrepreneur's ability, product ideas or business plans. In addition, start-up companies might be at a disadvantage as they frequently lack a rating history. This shift in credit assessment by banks could therefore raise the cost of credit for SMEs and restrict the availability of their financing. Given the importance of these firms for the EU economy, this might ultimately have a negative effect on economic growth, employment and innovation. A number of authors have studied this issue in detail, e.g. Fabi et al. (2004) or Dietsch and Petey (2004).

In its finalisation of the new capital rules, the BCBS made several adjustments to alleviate these concerns. As explained in greater detail in Section 2.2.1, under certain conditions, exposures to small businesses can under the standardised and the IRB approaches qualify for the preferential treatment of retail exposures. In addition, the IRB approach also provides for lower risk weights for SMEs that continue to fall under the corporate treatment. 
The potentially negative effect on SMEs was a major reason behind the 2002 European Council request to the European Commission to present a report on the consequences of the Basel II Framework for all sectors of the European economy, with particular attention to SMEs. In this "Barcelona report", it was concluded that the new capital rules would present an overall beneficial outcome for the vast majority of SMEs (PricewaterhouseCoopers, 2004). Therefore, the proposed EU rules for the treatment of SMEs do not deviate from those adopted by the BCBS. Overall, the discussion on the potentially adverse effects of Basel II on small and medium-sized enterprises has now lost its earlier intensity as the most significant concerns have been addressed through specific modifications to the Framework.

\section{(g) Procyclicality}

Procyclicality in the context of Basel II refers to the exacerbation of the economic cycle as a consequence of the new capital requirements. In a period of strong economic growth, banks may make more financing available at more generous conditions, possibly resulting in an asset boom, while in an economic downturn the reverse could take place, resulting in a credit crunch. Procyclicality is not a typical European concern, but the EU rules provide for a specific monitoring arrangement, as well as a role for the ECB. The topic of procyclicality is discussed in greater detail in Section 4.

\section{(h) The consolidating supervisor}

The increase of cross-border banking in the EU and the emergence of pan-European institutions have increased the need to strengthen cooperation and convergence in supervisory practices and requirements. To meet this need, the EU capital framework has enhanced the role of the "consolidating supervisor", which is the authority responsible for the supervision of a banking group on a consolidated basis.

This is an important innovative aspect of the EU capital framework that should foster supervisory convergence, financial integration and financial stability. It has also been identified as crucial by major cross-border institutions, which have been vociferous in publicly stating that the current provisions are too modest and that they would like to see an even more prominent role for the consolidating supervisor. This issue will be more extensively discussed in Section 5.

\section{(i) Real estate lending}

The rules regarding the treatment of residential and commercial real estate lending have been adapted to the EU context. The aim is to have a consistent treatment for both types of lending under the different approaches. Accordingly, the same eligibility criteria for the recognition of real estate collateral will be used both under the standardised and the foundation IRB approach. In addition, minimum requirements to ensure reliable collateral management and prudent valuation of mortgage property are applicable to all approaches. This issue will be addressed more extensively in Section 6.

\section{(j) Covered bonds}

Covered bonds have a key role in European capital markets and in the funding of mortgage and public sector lending. They encompass debt securities issued by EU banks that are subject to particular collateral arrangements under public regulation and supervision. As yet another distinct feature of the European landscape, they have a specific treatment in the new EU rules, whereas they are not addressed under Basel II. This topic will be addressed in greater detail in Section 7. 
PART II - ISSUES OF SPECIFIC RELEVANCE IN THE EU CONTEXT

\section{PROCYCLICALITY \\ 4.I DEFINITION}

During the development of the New Framework many observers pointed out that the new rules might lead to increased procyclicality in the financial system. The ECB has also repeatedly commented on this issue. ${ }^{23}$ Procyclicality refers to the empirical observation that banks' loan business tends to follow the same cyclical pattern as that of the real economy. Hence, loans typically show strong growth in an economic upturn and slow growth or even contraction in an economic downturn. In general, banks' lending activities show procyclical characteristics regardless of the design of capital requirements. This arises, for instance, on account of the existence of asymmetric information or market imperfections. In the context of Basel II, the discussion focuses on the potential for additional procyclicality as a result of the new capital rules.

Basel II may give rise to procyclical effects owing to the fact that the three main input parameters of the IRB approach are themselves - albeit to different degrees - influenced by cyclical movements. As regards the role of PDs, an economic downturn may lead to an increase in banks' estimates of borrower PDs if banks use a short-term assessment horizon. Such a "point-in-time" rating changes due to variation in the credit quality over the course of the business cycle. By contrast, a "through-thecycle" rating requires a longer-term analysis of borrowers' default risk on the basis of a scenario which takes into account the effect of, for example, an economic slowdown. In the case of the LGD, the losses that occur in the event of a default may increase in an economic downturn, because there is some evidence that recoveries from defaulted debt are lower in a recession. Finally, the exposure at default of a loan may also increase as borrowers make more use of their loan commitment limits during a downturn.

These arguments indicate that, in an economic downturn, the higher risk sensitivity of banks' rating systems may lead to rising capital requirements. In the event of a pronounced recession, banks' capital ratios may even fall close to the $8 \%$ minimum level. If banks are unable to adjust their capital level directly, they may have to reduce their lending to a level below that caused by the weaker demand in a recessionary environment. This potentially reduced availability of new bank lending could then exacerbate the downturn.

\subsection{EMPIRICAL EVIDENCE}

As regards research on procyclicality, the analysis has so far mainly concentrated on the behaviour of bank lending during past recessions, such as the US slowdown in the 1990s. Lowe (2002) and Allen and Saunders (2004) survey the literature on procyclicality. Key empirical studies on procyclicality are Kashyap and Stein (2003), Catarineu-Rabell et al. (2003), and Gordy and Howells (2004).

Kashyap and Stein (2003) document comprehensive evidence for procyclical effects in capital requirements during the 1998-2002 economic downturn. In their analysis, particular attention is given to methodological problems. The paper applies three alternative credit risk approaches, namely Standard and Poor's credit ratings, Moody's KMV model ${ }^{24}$ and a major international bank's internal credit risk model. All three methods lead to economically significant increases in capital requirements due to the time-varying risk weights. Rating agency estimates for credit risk, which should in principle take a longer horizon, lead to increases of between $30 \%$ and $45 \%$, whereas more "point-in-time" models

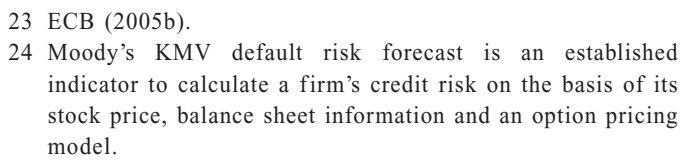
indicator to calculate a firm's credit risk on the basis of its stock price, balance sheet information and an option pricing model. 
produce capital increases of between $70 \%$ and $90 \%$. The authors also discuss possible policy measures to mitigate these effects.

Catarineu-Rabell et al. (2003) use both a theoretical general equilibrium model of the banking system and an empirical analysis to evaluate how the choice of a particular credit risk assessment system affects the likelihood of sharply increasing capital requirements in recessions. The authors demonstrate that a "point-in-time" approach could substantially increase procyclicality. The results also indicate that not all banks might use "through the cycle" rating systems, therefore raising important policy conclusions for the implementation of the Framework. Hence, the authors argue that banks should receive incentives to choose more stable credit risk assessment systems. According to the authors, few banks have sufficient capital to cover the increased capital requirement in a recession.

Gordy and Howells (2004) undertake a comprehensive simulation to investigate the impact of three measures to mitigate procyclicality. They point out that most of the literature focuses on procyclicality in Pillar I and the different ways to smooth it. According to the authors, smoothing necessarily affects risk sensitivity. Hence, investors will not be able to infer changes in portfolio risk from changes in capital ratios. In order to comply with Pillar III, they suggest an alternative solution which consists of dampening the output instead of the input. Here, the suggestion focuses on the design of an autoregressive rule that only allows for a partial adjustment of regulatory capital from one period to the other. Therefore, sudden changes of capital requirements would be smoothed and procyclicality would be alleviated. This rule should be made public to investors, who would then be able to infer the level of current unsmoothed capital requirements.

Marcelo and Scheicher (2005) use Moody's KMV model and a hypothetical portfolio of loans to 6,000 large, non-financial EU firms to estimate the foundation IRB capital
Chart 7 Difference in sensitivity of capital requirements for exposures on EU firms in a "point-in-time" and "through-the-cycle" approach (percentages)

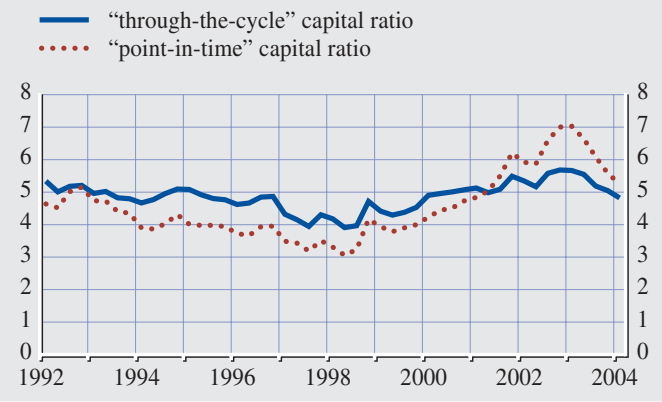

Source: Marcelo and Scheicher (2005).

requirements. The paper aims to replicate, as closely as possible, the implementation of a foundation IRB approach using both a "pointin-time" approach and a "through-the-cycle" perspective. Two main points emerge in the results (see Chart 7). First, banks' regulatory capital requirements under the IRB approach remain below $8 \%$ for the hypothetical EU15 corporate portfolio, the median capital requirement being $4.9 \%$ and the standard deviation $0.4 \%$. In this context, it is important to bear in mind that the estimated decline in regulatory minimum capital requirements relative to Basel I does not automatically mean a decline in the overall capital held by banks to cover the risks. Second, the "through-thecycle" approach indeed overall produces relatively low capital volatility.

Other studies arrive at similar conclusions about the potential weight of procyclicality. ${ }^{25}$ Altman et al. (2005) undertake an extensive simulation exercise with annual ratings transition matrices over the period 1981-2000. Allowing for positive correlation between LGDs and PDs, the cyclicality of capital charges is increased. Hence, if banks can also use internal estimates of LGD, their sensitivity to economic cycles might rise. According to

25 See also Carling et al. (2002), Segoviano and Lowe (2002), Illing and Paulin (2004), Amato and Furfine (2004), Goodhart and Segoviano (2004), Roesch (2005) or Hoffmann (2005). 
Bangia et al. (2002), US banks may require from $25 \%$ to $30 \%$ more capital in a recession than in a growth period. Finally, Berger and Udell (2003) argue that problems in loan performance are partly caused by changes in bank behaviour during economic expansions. In these periods, higher risk loans are provided and the problems then materialise during the following downturn. The cyclical variation in loan officers' credit standards would be a key factor in explaining this phenomenon. The authors test the empirical implications of this hypothesis using a US sample over the period 1980-2000 and find empirical support for it.

\subsection{MITIGATING MEASURES}

In order to address procyclicality concerns, the Basel II Framework includes a number of specific measures, some of which were already included in the $\mathrm{CP} 3 .^{26}$ In particular, under Pillar II, banks are asked to evaluate their risk bearing capacity with respect to scenarios which would particularly affect their credit exposures. In addition, banks using the IRB approach are required to implement a more specific credit risk "stress test" to evaluate how certain specific events affect their capital requirements. For this purpose, the banks' analysis should take into consideration at least the impact of mild economic downturns such as two quarters of zero GDP growth. In general, the development of reliable stress tests for credit risk under the IRB approach is still the focus of analytical work. It is therefore advisable that both banks and supervisors devote further efforts to developing suitable methodologies.

Given the potentially cyclical behaviour of minimum capital requirements, banks could pre-emptively set aside sufficient capital in the form of buffers over and above the regulatory minimum. Such buffers, which are encouraged under Basel II, can diminish the potentially negative macroeconomic effects of a downturn. In some EU countries (e.g. Spain), the practice of "dynamic provisioning" is actively encouraged by the supervisor. Under this approach, the possible loss over the whole life of the loan is taken into account in the provisioning process, thereby giving due consideration to the loan's full risk profile over the whole business cycle.

Finally, banks should in their assessment of the borrowers' credit risk under the IRB approach draw on a longer time horizon ("through the cycle" approach). This is particularly relevant in the case of banks lending to firms in cyclically sensitive sectors, which should be more conservative in their assessment of the default risk in periods of upturn. Banks are also required to use for their own LGDs and EADs values that have been estimated under the scenario of an economic downturn.

Overall, it can be concluded that procyclicality concerns were extensively addressed when the New Framework was being developed. As compared with earlier drafts of the Framework, the scope for such effects has been clearly reduced. The potential tools to reduce the creation of additional procyclicality in the financial system, such as forward-looking credit risk assessments, stress tests and dynamic provisioning, should in this context be seen as complementary measures and exploited to the maximum possible extent. EU supervisory authorities have a common interest in considering appropriate ways to reduce the risk of increased procyclicality, since macroeconomic conditions are gradually becoming more closely interwoven, particularly in the euro area.

\subsection{MONITORING IN THE EU}

From the discussion above, it should be clear that procyclicality resulting from the new capital rules is not a typical EU concern, but relates to the general design of the Framework. The abovementioned "Barcelona report", which is an impact study for the EU of the new capital rules, concluded that the New Framework is unlikely to

26 The CP3 reduced the slope of the risk weight curve, which expresses the relationship between the PD and the risk weight. 
significantly amplify the economic cycle. However, it also said that the European Commission and national authorities should keep this issue under review, during the initial transition stage and in the medium term, and stand ready to amend the Framework should this assessment prove too optimistic.

To this end, the CRD provides for specific monitoring arrangements to tackle procyclicality once the New Framework is fully implemented. The European Commission, together with the Member States, is required to periodically monitor the possible effects of the CRD on the economic cycle. In this process, a contribution from the ECB has to be taken into account. The European Commission has then to report on a biennial basis to the European Parliament and the Council and, if deemed necessary, propose measures to address the concerns.

\section{HOME-HOST ISSUES AND THE CONSOLIDATING SUPERVISOR}

\section{I INTERNATIONAL AND EUROPEAN CONTEXT}

Banks typically perform their foreign activities via branches and subsidiaries, ${ }^{27}$ which can result in complicated group structures. The New Framework will increase the need for cooperation between the supervisors of these different group entities because the capital rules apply at each level of the banking group. The implementation of the new rules may therefore require the group to obtain approval for its use of certain approaches from host supervisors on a solo or sub-consolidated basis, as well as from the home supervisor for the (top) consolidated level. ${ }^{28}$ By indicating the number of different countries where a selected set of EU banking groups has subsidiaries, Table 2 provides an indication of the potential complexity involved in the cooperation between home and host authorities.

In order to assist national authorities in this complex issue, the BCBS has developed guidance on how the new capital rules should

27 In addition, banks can also directly provide services on a cross-border basis; this third possibility is not discussed any further in the text. Branches, in contrast to subsidiaries, are not separate legal entities; in the EU they benefit from the "single passport" and "home country" control.

28 The supervisor of a foreign establishment of a banking group, be it a branch or subsidiary, will be referred to in the text as the host supervisor. In the event that it is necessary to make clear the type of local establishment, the terms hos branch supervisor or host subsidiary supervisor may be used. This terminology is not consistent with that used in the EU directives, where the term host supervisor is reserved for the supervisor of a foreign branch, but which is clearer to explain the practical arrangements for the supervision of a banking group.

\begin{tabular}{|c|c|c|c|c|}
\hline \multicolumn{5}{|l|}{ (EUR billlions; end 2003) } \\
\hline Group name & $\begin{array}{r}\text { Total } \\
\text { consolidated } \\
\text { assets }\end{array}$ & EU 15 & EU 25 & World \\
\hline Deutsche Bank & 804 & 8 & 10 & 18 \\
\hline BNP Paribas & 783 & 6 & 9 & 20 \\
\hline Royal Bank of Scotland & 638 & 2 & 2 & 5 \\
\hline ABN Amro & 560 & 5 & 6 & 17 \\
\hline Fortis & 425 & 5 & 6 & 10 \\
\hline Dexia & 349 & 7 & 8 & 11 \\
\hline Banco Santander Central Hispano & 346 & 5 & 5 & 18 \\
\hline Nordea & 262 & 4 & 5 & 6 \\
\hline Banca Intesa & 259 & 4 & 6 & 8 \\
\hline Danske Bank & 243 & 2 & 3 & 3 \\
\hline
\end{tabular}

Source: Bankscope.

Note: Because of limitations of the database, the table might not be complete. 
be implemented on a cross-border basis. ${ }^{29}$ These state that the legal responsibilities of national supervisors remain unaffected by the New Framework, although the home supervisor has a key role in overseeing the implementation process. The principles further stress the need for enhanced cooperation and due recognition of the host supervisors' concerns. Finally, the BCBS is also sensitive to the issue of increased compliance costs as supervisors have to avoid redundant and uncoordinated approvals.

These considerations are even more valid in the EU, where the Single Market and the single currency have given a significant impetus to cross-border banking. Here, the existing arrangements between home-host authorities have come under increased pressure and will even more so under the new capital rules. Moreover, the rules also introduce new requirements in terms of risk management and reporting systems, which result in higher compliance costs for banks. To alleviate some of these concerns, the CRD streamlines the interaction of the group with its different supervisors, in particular for prudential reporting and the approval of internal methods to calculate capital requirements. Whereas Basel II has kept the legal responsibilities of national supervisors unchanged, the CRD provides for an enhanced role of the "consolidating supervisor", the supervisor responsible for the consolidated supervision of a banking group.

However, giving a more prominent role to the consolidating supervisor, which is as a rule from the Member State where the bank heading the group is based, raises delicate questions about host authorities continuing to have sufficient powers and information regarding their banking systems. Chart 8 illustrates that this is particularly relevant for the new Member States. In most of them a large share of the local banking market is foreign-controlled and some of these foreign presences can even be qualified as systemically relevant. For the time being, this presence mainly takes the form of subsidiaries, where the primary supervisory

\section{Chart 8 Market share of foreign-owned banks in the new EU Member States}

(percentages; end 2003)

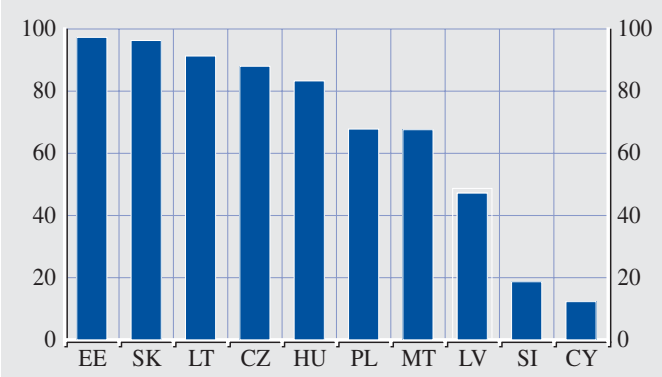

Source: Own calculations on the basis of ECB (2005c). Note: Market shares are calculated on the basis of total banking assets.

responsibility continues to rest with the host authority, even under the CRD. However, if these subsidiaries were to be transformed into branches, large segments of local banking sectors would become directly supervised by authorities from other EU Member States. Such a prospect has become nearer with Nordea's plans to create a one-bank structure, based on the European Company Statute, and conduct business in local markets through branches. ${ }^{30}$

\subsection{POWERS AND RESPONSIBILITIES OF THE CONSOLIDATING SUPERVISOR}

The consolidating supervisor, also known as the consolidated supervisor, is responsible for the group-wide supervision of a banking group. ${ }^{31}$ The debate surrounding the consolidating supervisor is sometimes obfuscated by the use of similar terms which cover very different meanings (see Box 4). All these terms refer to the supervisor who takes a group-wide perspective, but the extent of his or her responsibilities and powers, and the way they interact with the solo supervision of group entities, differ strongly. At the one end of the spectrum, the supervisor only coordinates the collection and dissemination of information

29 Basel Committee on Banking Supervision (2003 and 2004b). 30 Nordea (2003).

31 The CRD does not explicitly use these terms, but rather refers to "the competent authority responsible for exercising supervision on a consolidated basis". 
("coordinating supervisor"), thus leaving the powers of host subsidiary supervisors intact. At the other end, the supervisor assumes almost all the powers of the host supervisors ("lead supervisor"). The CRD approach regarding the extended function of the consolidating supervisor lies somewhere in between these two models.

Under the CRD, the consolidating supervisor continues to check compliance with supervisory requirements on a consolidated basis, as under the $\mathrm{CBD}$. The consolidating supervisor has also been allocated responsibilities similar to those of the coordinating supervisor under the Financial Conglomerates Directive. Moreover, additional tasks not explicitly listed may be conferred upon him or her, which will have to be specified in the written cooperation agreement that the consolidating supervisor has to conclude with the host subsidiary authorities. Finally, and more controversially, in certain cases, the decisions of the consolidating supervisor will be binding for the host supervisors.

In more detail, the tasks of the consolidating supervisor are as follows:

- Supervisory overview and assessment of compliance with supervisory requirements. This covers the supervision of a parent

\section{Box 4}

\section{OTHER SUPERVISORY ARRANGEMENTS FOR FINANCIAL GROUPS}

\section{Coordinating supervisor}

The concept of a coordinating supervisor or coordinator is rooted in the Financial Conglomerates Directive. ${ }^{1}$ Under this the coordinating supervisor is allocated the following tasks:

- to perform a supervisory overview and assessment of compliance with supervisory requirements in areas such as capital adequacy, risk concentration and intra-group transactions;

- to coordinate the gathering and dissemination of information;

- to plan and coordinate supervisory activities;

- to take certain technical decisions (e.g. relating to the identification of the conglomerate, supervisory reporting); and

- to undertake any additional tasks not mentioned in the Directive and conferred upon him or her.

\section{Lead supervisor and college of supervisors}

The concept of lead supervisor is associated with the proposals by the European Financial Services Round Table (EFR). ${ }^{2}$ The EFR starts from the concepts of coordinating and consolidating supervisors, but brings them further by recommending that the principle of home country control is extended from branches to subsidiaries. In this way, the lead supervisor becomes responsible for the supervision of the banking group at the different (sub)consolidated

1 Directive 2002/87/EC. The Financial Conglomerates Directive is to a large extent based on earlier work by the Joint Forum, see in particular the coordinator paper, Joint Forum (1999).

2 European Financial Services Round Table (2004 and 2005). The EFR was formed in 2001 to provide an industry voice on European policy issues related to financial services. Its members comprise the chairpersons or chief executives of 20 leading European financial institutions. In its report, the EFR mentions that the lead supervisor may also be called the consolidating supervisor. 
and solo levels. The lead supervisor would be the single point of contact of the banking group with its supervisors and would decide on all reporting schemes at the different levels of the group. In the area of capital requirements, he or she would decide on the supervisory review process ("Pillar II") at the different levels, validate and authorise internal models for capital requirements and approve the allocation of capital in the group. Host subsidiary supervisors in the EFR proposal would still be involved via the college of supervisors that would act as a forum for information exchange, discussion and provision of advice. However, it would not be a decision-making body, as only the lead supervisor has the power to take decisions.

To achieve this model, the EFR suggests making extensive use of the delegation of supervisory powers that is already in the $\mathrm{CBD}$, by formalising it in a memorandum of understanding and giving it a sound legal basis (preferably) in an EU regulation. The CBD already provides for the possibility of delegating supervisory powers and tasks. However, it seems that up to now this possibility has not often been used, in particular for subsidiaries. This may be due to the legal uncertainty regarding the liability of supervisors in case of such delegation. A complicating factor is also that cost sharing arrangements must be agreed for the performance of tasks on behalf of another supervisor.

The terms "lead supervisor" and "college of supervisors" were already used for the supervision of insurance groups although the content of the terms differ somewhat from the EFR concepts. The Insurance Groups Directive ${ }^{3}$ is the legal basis for the cooperation between insurance supervisors, and the "Helsinki Protocol" (2000) gives guidelines on how such cooperation should work in practice. The Protocol provides for a college of supervisors, called a coordination committee, and the lead supervisor. The latter will in practice carry out most of the work of the group-wide supervision by pulling together all relevant information, analysing it and sharing the findings with the coordination committee. Such a lead supervisor can only be appointed if there is unanimity within the committee; in general, the lead supervisor will be the supervisor of the country where the group has its dominant insurance undertaking. The coordination committee itself is composed of supervisors of all countries in which the group has undertakings and who are involved in its day-to-day supervision.

3 Directive 98/78/EC

bank's compliance with supervisory requirements on a consolidated basis. Areas covered are: (i) the minimum level of own funds under Pillar I, (ii) limits regarding shareholdings held outside the financial sector, (iii) the process to assess that adequate "internal" capital is available, (iv) large exposures requirements, (v) disclosure requirements, (vi) robust governance arrangements.

- Coordination of the gathering and dissemination of information. The coordinating supervisor has to provide the host subsidiary supervisors with all the relevant information they need for the supervision of these subsidiaries. The coordinating supervisor also has a particular information duty in the event that an emergency situation occurs that threatens the stability of the financial system, when he or she has to alert the central banks and Ministries of Finance concerned.

- Planning and coordination of supervisory activities. Particular reference is made to the review of compliance with the CRD requirements and the evaluation of risks by competent authorities under Pillar II and inspections of foreign branches and subsidiaries in the Member States. 
The parent and the subsidiaries of a banking group will be able to jointly apply to use IRB approaches to calculate capital requirements for credit risk, AMA for operational risk and the recognition of internal models for market risk. In that case, the competent authorities have to work together on whether or not to grant permission, and if so under what conditions. Such an application has to be submitted only to the consolidating supervisor. The competent authorities have to decide on the application within six months in a single document. In the absence of an agreement among the authorities involved, the consolidating supervisor shall take its own decision. This last element in particular has caused controversy as it shifts powers from the supervisors of subsidiaries to the consolidating supervisor.

\subsection{ASSESSMENT OF THE CONSOLIDATING SUPERVISOR}

The more prominent role of the consolidating supervisor in combination with the enhanced information exchange between supervisors provided for by the $\mathrm{CRD}$, is beneficial to financial stability and financial integration. First, the arrangements ensure that the consolidating supervisor has a comprehensive group-wide view, while the host subsidiary supervisors will have easier access to group information that might be relevant for the entities they supervise.

Second, for banking groups, the new arrangements lead to a more streamlined interaction with their different supervisors and lower compliance costs. The risk of different, inconsistent or even conflicting, supervisory approaches is therefore significantly reduced. Since large cross-border groups typically organise some of their key business functions on a group-wide basis, it also leads to a better match between the way they are supervised and managed. Finally, it contributes to the creation of a level playing-field for European financial institutions in the international market. A panEuropean group that has to deal with multiple supervisors, for example, to get its internal risk models approved, has a competitive disadvantage compared with its US counterpart that needs to submit only one such application.

Notwithstanding these potential benefits, the issue of the consolidating supervisor also raises complex implementation questions. First, at present, the powers, resources and experience of national supervisors differ substantially. These differences are rooted in factors such as the size of the financial system, the way the supervisor is financed, political choices and supervisory approach. Not all countries therefore have the resources or knowhow to act as the consolidating supervisor of major international banking groups.

Second, notwithstanding the ultimate decisionmaking power of the consolidating supervisor regarding the approval of group-wide methods, it is important that any disagreements with host subsidiary supervisors are adequately addressed so as not to undermine the powers of the host supervisors. For example, although the consolidating supervisor would approve groupwide advanced calculation methods for capital requirements, it is not clear how this would relate to the responsibility of the ongoing supervision of these methods.

In this context, it is advisable that guidance is developed for the cooperation between the consolidating supervisor and the host subsidiary supervisors, an area in which the CEBS is already active. ${ }^{32}$ The CEBS is developing its guidance along a risk-based and proportional approach. Hence, the degree of information exchange and cooperation between supervisors should be related to the importance of the subsidiaries, both in relation to the host local market and the group as a whole. In order to avoid uncertainty, it is important that such arrangements are formalised via memoranda of understanding (MoU). A certain degree of flexibility is needed in such MoUs to accommodate the specific features of an individual group. At the

32 See in particular the CP9 of the CEBS 
same time, standardisation and supervisory convergence should be aimed at ensuring a level playing-field.

Third, in the event that the consolidating supervisor takes a different stance to that of the host subsidiary supervisor on certain prudential issues, this could lead to a competitive distortion within national markets. In particular, institutions that are not part of a wider group (e.g. local cooperative banks or savings banks) could be disadvantaged compared with institutions that belong to a group in case the consolidating supervisor takes a more lenient stance. Similarly, banks that are part of a group with a different consolidating supervisor may be treated differently, which calls for supervisory convergence through the CEBS.

Fourth, the granting of more powers and responsibilities to the consolidating supervisor should not lead to a disconnection between the responsibilities for prudential supervision and other closely related areas of public policy. These include financial stability monitoring, the management of deposit insurance, emergency liquidity assistance and tax payer support. Most of these areas continue to be organised on a national basis and the involvement of a consolidating supervisor in the supervision of locally licensed institutions might create difficulties.

Banking supervisors have a national mandate and are accountable to national political bodies such as ministries of finance and parliaments. The latter are primarily concerned about the impact on the national financial system or budget. The commitment of a foreign supervisor to entities in the host country may therefore not be fully credible. In particular, this is the case when the parent bank is not systemically relevant in its home country, but the subsidiary in the host country is. In this scenario, it seems unlikely that the home supervisor would have an equally strong incentive to monitor or intervene in the local subsidiary as the host authority. Moreover, in the event of any public financial intervention to support the group, in relative terms, it would benefit the host country more than the home country.

Finally, one should note the views of the industry, which is pursuing an enhanced role for the consolidating supervisor. The European Banking Federation has already expressed its disappointment and continues to plead for an extension of the responsibilities of the consolidating supervisor to Pillars II and III, turning his or her role into that of a real "lead supervisor". The supervisory community continues to be reluctant to support this model, advocating instead increased supervisory cooperation in combination with supervisory convergence. In general, supervisors do not see a need for any change in the legal responsibilities between home and host. However, there are other supervisors who take a rather sympathetic view towards the lead supervisor (Brouwer, 2004). Given the abovementioned considerations, it seems preferable that before moving towards the path of the lead supervisor, more experience is first gained with the actual working of the extended role of the consolidating supervisor and the potentialities offered by the Lamfalussy framework.

\section{REAL ESTATE LENDING}

\section{I OVERVIEW}

The differences between Basel II and the EU rules are particularly visible in the treatment of residential real estate (RRE) and commercial real estate lending (CRE) under the standardised approach. The regulatory treatment of such lending is of great importance given the high share of bank loans it accounts for in the EU. Chart 9 gives an indication of this and, since it does not include commercial real estate lending, reflects an even larger significance than is suggested by the figures. Moreover, CRE lending has been a recurring cause of problems in the banking industry over the past decades (e.g. the savings and loans crisis in the US, the 
Chart 9 Loans for house purchases as share of total loans to non-banks

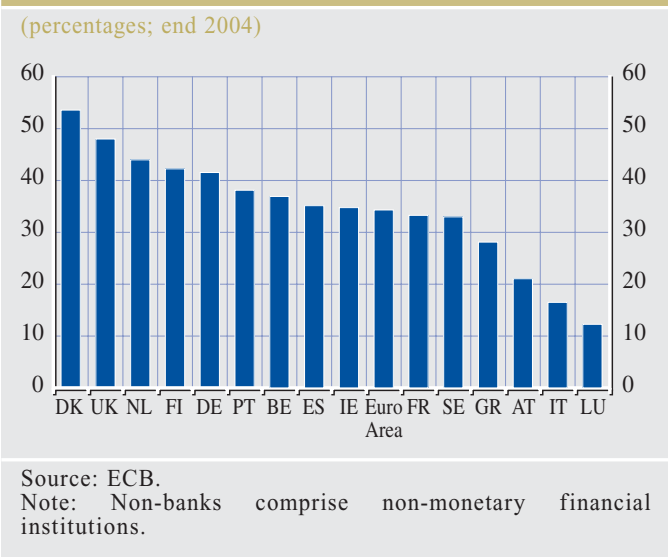

Swedish banking crisis), warranting a particularly prudent approach.

The BCBS provides for the preferential capital treatment of certain types of real estate lending in case it is secured by mortgages. This preferential treatment applies to both the standardised approach and the foundation IRB, subject to stringent conditions to assure that the lending exhibits low risk.

The EU rules are not a direct transposition of Basel II. From the outset, the European Commission aimed to be as consistent as possible in its treatment of RRE and CRE lending across the different approaches. The Commission therefore extended the Basel II conditions for preferential treatment under the foundation IRB approach to the standardised approach. Hence, the differences between Basel II and the EU rules are especially manifest in the standardised approach, on which this paper focuses.
Although the Commission's proposals received criticism from the industry because they were more stringent than Basel II in certain respects, ${ }^{33}$ the Commission maintained its original position. The EU rules therefore have the merit of achieving a high degree of consistency between the standardised approach and the foundation IRB. As explained below, to some extent this comes at the expense of a less conservative treatment of CRE. However, in the specific field of CRE that produces income to service the debt, the EU rules apply the same criteria as Basel II. This is important from a financial stability point of view, given the lower additional protection provided by that type of collateral.

\subsection{RESIDENTIAL REAL ESTATE}

The preferential risk weights for secured RRE lending under the standardised approach are identical under Basel II and the CRD. However, the difference lies in the criteria to be met for these lower risk weights (see Table 3). The main difference is that the CRD imposes two independence criteria. ${ }^{34}$ By contrast, Basel II does not impose these criteria under the standardised approach, but only under the foundation IRB. Hence, in this respect the EU rules are more conservative.

The first independence criterion (borrower risk does not influence property value) is typically given for RRE. The exception might be the case

33 European Mortgage Federation (2003).

34 Where independence of collateral value and borrower default risk is not given, the additional protection from the collateral is limited. This is often referred to as "wrong-way" risk.

\begin{tabular}{|c|c|c|}
\hline & Basel II & CRD \\
\hline $\begin{array}{l}35 \% \text { risk weight for RRE lending instead of } 100 \% \\
\text { 1. Over-collateralisation } \\
\text { 2. Property value not materially depending on borrower credit quality } \\
\text { 3. Borrower risk not materially depending on collateral value }\end{array}$ & $\begin{array}{l}\text { Yes, but not quantified } \\
\text { No } \\
\text { No }\end{array}$ & $\begin{array}{l}\text { Yes, but not quantified } \\
\text { Yes } \\
\text { Yes, but may be waived if } \\
\text { loss rates in the jurisdiction } \\
\text { are "sufficiently low" }\end{array}$ \\
\hline
\end{tabular}


of very special property that is tailored to individual needs and is therefore difficult to resell.

The second independence criterion (property value does not influence borrower risk) is a constraining factor when the borrower has to rely on the collateral's rental income to serve the loan. This criterion would exclude from the preferential treatment firms that specialise in owning and letting residential real estate. In these cases, the collateral offers only limited additional protection compared to an unsecured loan because the default of the borrower will typically result from insufficient rental income. Under such conditions, it is very likely that the property value as derived from the discounted net rental income will also have been negatively affected.

The fact that the borrower relies on the income from the collateral does not necessarily mean that the credit risk of such exposure is similar to that of an unsecured exposure. More specifically, the credit risk will depend on how the loss expectation in RRE lending compares with the loss expectation of other loans. In its proposal, the Commission assumed that the loss expectation in RRE lending varies among national markets. It also allows national authorities to dispense with the second independence criterion within their national market under certain conditions.

The condition for such a waiver is that the national authorities have evidence of loss rates that are sufficiently low to justify such treatment. Given that the CRD offers no guidance as to how to assess this, implementation efforts should focus on what constitutes sufficiently low loss rates. This is one of the fields where supervisors, through the CEBS, could achieve a harmonised implementation. Starting with an analysis of national loss rates and comparing them with loss rates for other asset classes, it should be possible to define a quantitative threshold. This common threshold would facilitate the mutual recognition of preferential risk weights and thereby promote the integration of a European market for RRE lending.

While data on loss rates for RRE lending are not readily available, the volatility of residential property prices can be assumed to be an important driver. In this respect, it is interesting to note that there are pronounced differences in the development of housing prices across Member States (see Chart 10). It is likely that these differences also translate into differences in loss rates.

Finally, a more subtle difference between Basel II and the EU rules is that, under the latter, the collateral must be used or rented-out by the owner, who may not be the borrower. Basel II, by contrast, requires this to be the borrower. In both cases, purely speculative holdings of property would be excluded. However, the CRD would allow for situations where a loan to a small firm (i.e. the borrower) is secured by a mortgage on the residence of the firm's owner. Such situations may be especially relevant for SMEs.

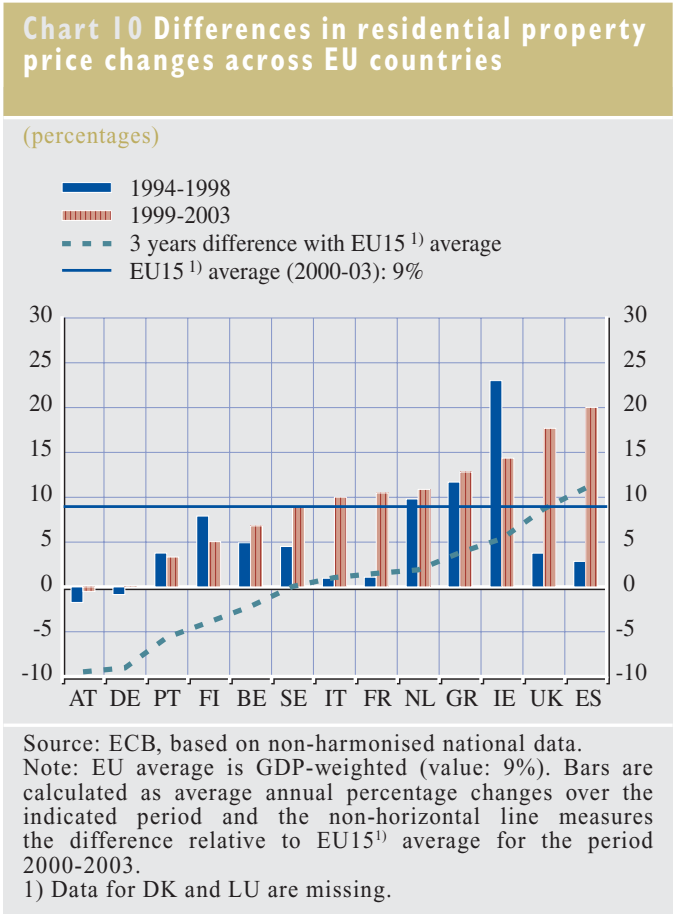




\subsection{COMMERCIAL REAL ESTATE}

CRE lending is a particularly sensitive area as, in the past, banking crises have sometimes coincided with a crisis in the commercial real estate market. Strict regulatory criteria have therefore to be met before such lending can benefit from a preferential capital treatment.

Under Basel II, the preferential treatment for CRE is only made available in national markets where the loss rates observed in the past do not exceed certain thresholds (see Table 4). The CRD, by contrast, is more flexible since it imposes the requirement on loss rates only in cases where the property value materially influences the borrower risk; this is basically where the borrower has to rely on the collateral's rental income to serve the loan. As a result, in the EU, jurisdictions where the thresholds are exceeded can also apply for a preferential CRE treatment. ${ }^{35}$ This extended preferential treatment reflects the fact that a loan to a firm that does not rely on real estate income is less risky than an otherwise identical unsecured loan.

Basel II specifically lists offices and multipurpose or multi-tenanted properties as eligible types of property. The CRD, by contrast, does not include a restriction on the type of premises, but imposes an abstract independence criterion for the property value not to depend on the borrower risk. This basically serves the same purpose as listing the property types, but gives more leeway for prudential judgement. With a view to achieving a level playing-field, it is important that European supervisors strive for convergence in this area.

Another distinguishing feature of the EU framework is the preferential treatment for CRE leasing. Such leasing can obtain the lower risk weight when the conditions for the recognition of mortgage lending are met. The only specific requirement is that the lessor, i.e. the party which rents out the property, retains full ownership in the same way as a mortgage lender. However, depending on the structure of the lease, a lessor may also be exposed to specific risks that are not incurred by a mortgage lender. For example, a lessor may incur a price risk when having to sell the property if it is not fully amortised. While such leasing-specific risks are not addressed in the CRD, a prudent implementation should only extend the preferential treatment to those leases under which the lessor bears risks that are not larger than those of a mortgage lender.

35 Under the foundation IRB, Basel II also allows for recognition of this loss-reducing effect. In this way, the Commission's proposal achieves higher consistency across approaches

\begin{tabular}{|c|c|c|}
\hline & Basel II & CRD \\
\hline \multicolumn{3}{|l|}{$50 \%$ risk weight for CRE lending instead of $100 \%$} \\
\hline $\begin{array}{l}\text { 1. Over-collateralisation (eligible lending may exceed neither } \\
50 \% \text { of market value nor } 60 \% \text { of mortgage lending value) }\end{array}$ & Yes & Yes \\
\hline 2. Property value not materially depending on borrower credit quality & $\begin{array}{l}\text { Yes, implicitly: } \\
\text { property must be offices } \\
\text { or multi-purpose/ } \\
\text { multi-tenanted }\end{array}$ & Yes \\
\hline 3. Borrower risk not materially dependent on collateral value & No & $\begin{array}{l}\text { Yes, but may be waived if } \\
\text { point } 4 \text { is met. }\end{array}$ \\
\hline $\begin{array}{l}\text { 4. Loss rates (as percent of outstanding CRE) in the jurisdiction } \\
\text { not in excess } 0.3 \% \text { on eligible loans and } 0.5 \% \text { overall }\end{array}$ & Yes & $\begin{array}{l}\text { No (i.e. not generally, } \\
\text { see point } 3 \text {.) }\end{array}$ \\
\hline
\end{tabular}




\section{I CONCEPT OF COVERED BOND}

The EU rules provide for a specific treatment of covered bonds, which is not present in Basel II. A covered bond is a secured bond issued by a bank or other financial institution. However, the security for the bond is not merely over the institution's assets generally but a designated pool of assets, typically mortgage loans or public sector loans, is specifically designated as collateral. Covered bonds differ from securitisation bonds in a number of important respects. First, bondholders have recourse both to the issuing institution and to the assets that provide cover for the bonds. Second, the bonds do not achieve off-balance sheet treatment as the asset pool that provides cover remains on the institution's balance sheet.

Such financing instruments are of great importance in the EU capital markets, although their significance differs across Member States (see Chart 11). Several Member States have in the recent past adopted legislation to allow the issuance of such bonds. It is therefore justified that the CRD takes account of this typical European instrument. Since the most common form (the German "Pfandbrief") is well-known outside European capital markets, even a specific treatment under Basel II itself might have been desirable.

The treatment of covered bonds under the EU rules is based on the legal definition of this instrument in the UCITS Directive (Undertakings for Collective Investment in Transferable Securities), ${ }^{36}$ which is very broad. It does not refer to an identical instrument in all Member States, but rather to a range of instruments that are not subject to harmonised rules at the EU level. In this way, the definition accommodates for the wide differences that exist in national laws on covered bonds in areas such as assets used as collateral, restrictions placed the issuing bank's activities, the degree of "over-collateralisation", and the way

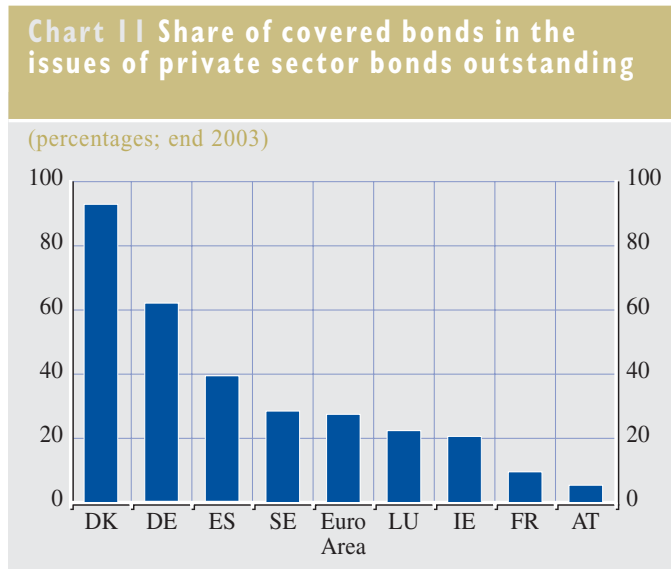

Sources: ECB and European Mortgage Federation.

bankruptcy remoteness is achieved. Overcollateralisation refers to the extent to which the value of the collateral has to be higher than the nominal value of the bond and bankruptcy remoteness ensures that the bond holders' access to the collateral is truly superior to that of all other creditors.

In the light of this diversity, the definition of covered bonds for the purposes of capital requirements is more restrictive as only specific assets - in some cases subject to overcollateralisation - may be used as collateral. The CRD lists in this context mainly:

- exposures that qualify for a $0 \%$ risk weight under the standardised approach. This includes exposures on central governments, central banks, multilateral development banks and international organisations. Exposures to other public sector entities, regional governments and local authorities may also be included if they are considered to carry the same credit risk as central governments;

- loans secured by residential real estate mortgages which, including prior liens, are no more than $80 \%$ of the value of the property; and

36 Directive 85/611/EEC, art. 22(4). 
- loans secured by commercial real estate mortgages which, including prior liens, are no more than $60 \%$ of the value of the property. The competent authorities may also recognise loans where this "loan-to-value" ratio is up to $70 \%$; the condition is that the value of the total assets pledged (i.e. not only the mortgaged assets) exceeds the outstanding amount of the bonds by at least $10 \%$;

Further, up to $10 \%$ of the outstanding covered bonds may be covered by exposures to banks and investment firms. In this way, the issuing bank may to a certain extent replace eligible collateral by deposits with banks of a high credit standing when collateral is scarce.

The additional restrictiveness under the CRD is not expected to lead to a large scale ineligibility of instruments that are issued under national legislations. Rather, the present range of covered bonds in the EU will also be eligible for the preferential capital treatment. For example, the "loan-to-value" limits for mortgage loans in the CRD reflect the highest thresholds present in these legislations, though a number of them are more conservative. For example, the $10 \%$ limit for the substitution of eligible assets by other assets such as bank deposits, is a possible constraint for some Member States that currently allow higher limits.

\subsection{CAPITAL TREATMENT}

The covered bonds that meet the CRD requirement are treated as exposures to banks. The risk weighting is based on the credit standing of the issuing bank, while at the same time recognising the effects of the collateral. The collateral is recognised in the form of reduced risk weights under the standardised approach or in the form of reduced LGDs under the IRB approaches.

Under the standardised approach, covered bonds receive reduced risk weights based on the weights of senior exposures to the issuer in the manner described in Table 5.

As regards treatment under the IRB approaches, the EU rules are fully consistent with Basel II, since a bank's internal rating system needs to comprise both a borrower and a facility dimension. Based on the borrower dimension, PDs are assigned to exposures, while the facility dimension underlies the assignment of LGDs. The collateral to which the bondholders have a preferential claim affects the facility dimension. While Basel II does not encompass any specific rules for covered bonds, the collateral of the bond would lead to a reduced LGD if the bank were able to get supervisory approval for an estimate of this collateral effect under the advanced IRB. Under the foundation IRB, such covered bonds may receive a reduced supervisory LGD of $12.5 \% .{ }^{37}$ The advanced IRB would require the investing bank to use its own LGD estimates for covered bonds. Under both the foundation and advanced IRB the risk weights continue to depend also on the PD of the issuer.

Chart 12 depicts the risk weights for all approaches. It shows that in many situations, the standardised approach will deliver the

\footnotetext{
37 Compare this with the supervisory LGD of $45 \%$ for senior claims and $75 \%$ for subordinated claims. For certain covered bonds, the LGD may further be reduced to $11.25 \%$ until the end of 2010 .
} 


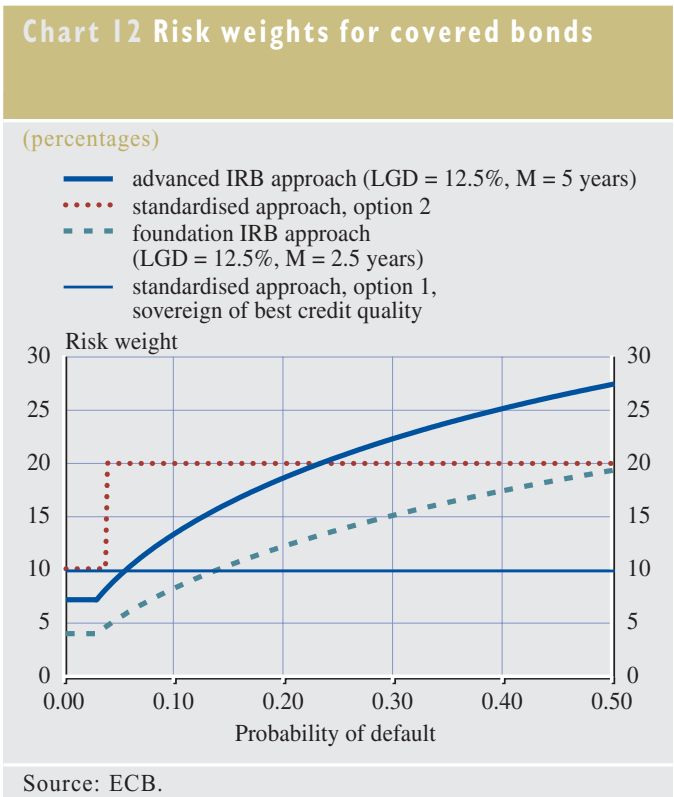

lowest risk weights for covered bonds in jurisdictions where risk weights for exposures to banks are based on the ratings of the sovereign ${ }^{38}$ and the sovereign itself receives a $0 \%$ risk weight. Only for issuers with very low PDs would the IRB approaches lead to lower risk weights. Default experience for corporate borrowers published by rating agencies suggests that this will only be the case for issuers whose rating for their senior debt is comparable to an S\&P rating of "AA" or better.

How the outcome under the advanced IRB relates to the other approaches depends very much on the assumptions for the M and LGD risk factors. For $\mathrm{M}$, one can assume the maximum possible value of five years given the usually long maturities of covered bonds. For LGD, Chart 12 assumes the same value as the supervisory LGD (i.e. $12.5 \%$ ) because there is a lack of default experience, a difficulty that banks under the advanced IRB will also face. On the basis of these assumptions, the advanced IRB appears unattractive compared with the foundation IRB because, under the latter, $M$ will in most cases be fixed at 2.5 years. However, this can change if a bank receives supervisory approval for lower estimates of LGD. ${ }^{39}$
Another observation from this comparison is that, in jurisdictions where risk weights for banks are directly based on their own ratings rather than on those of their sovereign, the resulting weights for covered and non-covered issues will often be the same. For example, when an issuer's senior debt has an S\&P rating of "A" under the standardised approach of Basel II it would receive a $50 \%$ risk weight. For the same issuer's covered bonds, a 20\% weighting would apply under the EU rules. But this $20 \%$ would often apply anyway, even without the specific EU treatment, given that covered bonds have typically issue specific ratings of "AA" or better that results in the same risk weight.

\section{CONCLUDING REMARKS}

This paper provides an overview of the New Basel Capital Framework from an EU perspective and discusses certain important issues relating to the implementation of Basel II in the EU. Despite the similarities between the draft EU framework and the BCBS proposal, a number of different treatments are justified by EU specificities.

The Basel II Framework is expected to foster stability in the EU financial system. This objective will be achieved by strengthening incentives for banks to conduct sound risk modelling and management, and by involving supervisors more directly in the review of banks' risk profiles, risk management practices and risk-bearing capacity. Furthermore, the new disclosure requirements will enable market participants to have better information on banks, which will support the functioning of market discipline. These beneficial effects on the financial system will also translate into a

38 This is the "Option 1" of the standardised approach; by contrast, under "Option 2", the risk weights for exposures on banks are directly determined on the basis of the banks' ratings and not on the basis of the sovereign's rating. See also Section 2.2.1.

39 With an LGD of less than 7\%, capital requirements for covered bonds under the advanced IRB $(\mathrm{M}=5$ years $)$ would be consistently lower than under the foundation IRB. 
positive contribution to the EU economy at large.

Notwithstanding, there are still a number of key challenges in the EU implementation process which need to be tackled in order to fully reap the potential benefits of Basel II. First, it is important to preserve a level playingfield across the EU. A consistent implementation of the EU rules into national legislation and a coherent application of the framework are therefore necessary. In this context, reducing the number of options in the draft EU capital requirements framework is a challenging task. The CEBS has already made progress here, which needs to be kept up. The EU will also have to follow-up closely on how Basel II will be implemented in the US and how the decisions by US authorities will interact with the activity of EU banks in the US and decisions by EU supervisors.

Second, the debate on the optimal design of the consolidating supervisor's functions continues as some of the largest firms want to move to the "lead supervisor" model. Although pursuing an enhanced role for the consolidating supervisor offers advantages from the perspectives of financial integration and financial stability, there remain a number of complex implementation issues that need to be taken into account.

Third, the potentially adverse effects of capital requirements on the EU macroeconomic environment require ongoing monitoring. This issue and the related question of the structural impact of the new rules on the financial system are of particular interest to many constituencies, including central banks. This explains the reference to the role of the ECB in the monitoring of possible procyclical effects in the CRD.

In the medium-term, a number of issues may potentially achieve increasing prominence. First, the impact of the new accounting measures on the capital definition may turn out to be quite important. Here, banking supervisors have already considered the interplay between the implementation of certain International Financial Reporting Standards (IFRS) and the definition of regulatory capital. There are also plans to carry out a more fundamental review of the definition of regulatory capital.

Another medium-term issue is the nexus of market and credit risk, which may bring the current market risk treatment under further scrutiny. As things stand, the border between the two risk categories is not very clear. Due to the improved abilities to trade, hedge and value credit risk related instruments, they play an increasingly significant role in the trading books of financial institutions. This, however, raises concerns over the prudence of the present simple approach to the specific market risk of debt instruments in the trading book. An example of this is the impressive development of credit derivatives and Collateralised Debt Obligations (CDOs). At this stage, the BCBS does not plan to issue new rules on the existing boundary between trading book and banking book, and only a limited number of adaptations to the current regime were recently adopted. However, in the future, the financial industry may call for a harmonised treatment of these two main risk categories. ${ }^{40}$

Finally, and in relation to the preceding issue, the use of credit portfolio management is undergoing significant changes. Banks have started to apply increasingly sophisticated portfolio approaches to their loan books. The modelling of credit correlations and portfolio diversification effects is a very active area of research, both among practitioners and academics. Hence, the BCBS's decision to limit recognition for regulatory capital purposes to the single risk factor IRB approach may come under increased scrutiny in the future.

40 Duffie and Singleton (2003) provide a detailed analysis of credit derivatives and also discuss the integrated modeling of market and credit risk. 
Advanced (calculation) approaches: methods available to banks to calculate their regulatory capital requirements based on own risk estimates. Includes the foundation and advanced internal ratings-based (IRB) approach for credit risk, the advanced measurement approaches (AMA) for operational risk, and the internal models approach for market risk.

Asymptotic single risk factor (ASRF) model: theoretical model underlying the risk weight function (which relates risk factors to risk weights) of the internal ratings-based approach.

Bamking b ook: the bank portfolio consisting of financial instruments that are not held for trading.

Capital ratio: ratio of regulatory own funds (core capital and supplementary capital) to total riskweighted assets. Also called solvency ratio.

Consolidating supervis or: the supervisor responsible for the supervision on a consolidated basis of a banking group. As a rule, this is the supervisor of the Member State where the parent bank of the group is based.

Core capital: regulatory capital that consists of own funds components of the highest quality, such as fully-paid capital and disclosed reserves from post-tax retained earnings. Also called Tier 1 capital.

Covered bond: a secured bond issued by a bank or other financial institution. The security of the bond is not merely over the institution's assets generally, but also over a designated pool of assets, typically mortgage loans or public sector loans.

Credit risk: risk of losses in on and off-balance sheet positions resulting from the failure of a counterparty to perform according to a contractual arrangement.

Double default: refers to the fact that the risk of both a borrower and a guarantor defaulting on the same obligation may be substantially lower than the risk of only one of the parties defaulting.

Economic capital: capital held and allocated by the bank internally as a result of its own assessment of risk. It can differ from regulatory capital, which is determined according to supervisory rules.

Effective maturity: remaining time before a borrower is scheduled to fulfil his obligation; one of the requested input parameters to derive the risk weight under the internal ratings-based approach.

Expected loss: (credit) losses that are expected to occur within a certain time period (generally one year).

Exposure at default (EAD): the exposure a bank is likely to have on a borrower at the moment the borrow defaults; one of the requested input parameters to derive the risk weight under the internal ratings-based approach. 
External credit assessment institution (ECAI): institution recognised by supervisors and whose assessments may be used to calculate regulatory capital requirements for credit risk under the standardised approach.

Intermal ratings-based (IRB) approach: advanced approach by which a bank can use its own credit assessments to calculate its regulatory capital requirements for credit risk. Depending on the risk factors the bank is allowed to estimate, a distinction is made between a foundation IRB and an advanced IRB approach.

Lead supervisor: supervisory model under which the consolidating supervisor would be the single supervisory contact point of a banking group, both for its branches and subsidiaries. In the area of capital requirements, the lead supervisor's tasks and responsibilities would extend to the three pillars of the New Framework.

Loss given default (LGD): the loss, measured as a percentage of the exposure at default, which is likely to occur in case a borrower defaults; one of the required input parameters to derive the risk weight under the internal ratings-based approach.

Madrid compromise: the agreement reached by the Basel Committee in January 2004 to calibrate the risk weight functions used in the internal ratings-based approach on the basis of unexpected credit losses only.

Market risk: risk of losses in on and off-balance sheet positions arising from movements in market prices and volatilities.

Operational risk: risk of losses resulting from inadequate or failed internal processes, people or systems, or from external events. It includes legal, but not reputational or legal risk.

Permanent partial use: in the context of credit risk, this refers to the combined use of the standardised approach for certain exposure classes whilst applying the more sophisticated IRB approaches for the remaining classes on a non-temporary basis.

Probability of default (PD): the likelihood that a borrower will default within a certain time period (generally one year); one of the required input parameters to derive the risk weight under the internal ratings-based approach.

Procyclicality: exacerbation of the economic cycle as a result of changes in regulatory capital requirements.

Quantitative Impact Study (QIS): data collection exercise organised by supervisors to assess the impact of the new capital rules on banks.

Regulatory capital (own funds): own funds that are eligible to meet the regulatory capital requirements; consist of core capital and supplementary capital, after a number of deductions. Regulatory capital is the numerator of the capital ratio.

Risk-weighted assets: risk measure that consists of multiplying each asset value by a factor (risk weight) that is a proxy of the (credit) risk related to the asset class. Risk-weighted assets are the 
denominator of the capital ratio. For operational risk and market risk, the risk-weighted assets that enter into the capital ratio are derived from the directly calculated capital requirements.

Solvency ratio: see capital ratio.

Standardised approach: method by which a bank can use external ratings (if available) by external credit assessment institutions to calculate its regulatory capital requirements for credit risk.

Supplementary capital: regulatory capital that consists of own funds of a lower quality than core capital, such as certain types of subordinated debt; also called Tier 2/Tier 3 capital.

Trading book: the bank portfolio consisting of financial instruments that are in principle held for short-term trading purposes, i.e. they are held intentionally for short-term resale and/or with the intent of benefiting from short-term price movements or to lock in arbitrage profits.

Unexpected loss: (credit) losses which may occur above the expected loss within a certain time period (e.g. one year) and within a high confidence level (e.g. 99.9\%). 


\section{REFERENCES}

Allen L. and Saunders A. (2004), "Incorporating systemic influences into risk measurements: a survey of the literature", Journal of Financial Services Research, vol. 26, No. 2, pp. 161-191.

Altman E., Brady B., Resti A. and Sironi A. (2005), “The link between default and recovery rates: implications for credit risk models and procyclicality", Journal of Business, forthcoming.

Amato J. D. and Furfine C. H. (2004) “Are credit ratings procyclical?”, Journal of Banking and Finance, 28(11), pp. 2641-2677.

Bangia A., Diebold F., Kronimus A., Schagen C. and Schuermann T. (2002), "Ratings migration and the business cycle, with application to credit portfolio stress testing", Journal of Banking and Finance, No. 26, pp. 445-474.

Basel Committee on Banking Supervision (2005a), "An explanatory note on the Basel II IRB risk weight functions", July.

Basel Committee on Banking Supervision (2005b), "The Application of Basel II to trading activities and the treatment of double default effects", July.

Basel Committee on Banking Supervision (2005c), Newsletter No. 4, January.

Basel Committee on Banking Supervision (2004a), "International convergence of capital measurement and capital standards", June.

Basel Committee on Banking Supervision (2004b), "Principles for the home-host recognition of AMA operational risk capital", January.

Basel Committee on Banking Supervision (2003), "High-level principles for the cross-border implementation of the New Accord", August.

Basel Committee on Banking Supervision (1996), "Amendment to the Capital Accord to incorporate market risks", January.

Basel Committee on Banking Supervision (1988), "International convergence of capital measurement and capital standards", July.

Berger A. and Udell G. (2003), "The institutional memory hypothesis and the procyclicality of bank lending behaviour", BIS, Working Paper No. 125.

Brouwer H. (2004), "Financial integration in the EU - some food for thought", Speech at the board meeting of the European Banking Federation, 5 November 2004.

Carling K., Jacobson T., Lindé J. and Roszbach K. (2002), "Capital charges under Basel II: corporate credit risk modelling and the macro economy", Sveriges Riksbank Working Paper Series, No. 142, September. 
Catarineu-Rabell E., Jackson P. and Tsomocos D. (2003), "Procyclicality and the new Basel Accord - banks' choice of loan rating system", Bank of England - Working Paper No. 181.

De Fontnouvelle P., Rosengren E. and Jordan J. (2004), "Implications of alternative operational risk modeling techniques", Mimeo.

Deutsche Bundesbank (2004), "New capital requirements for credit institutions", Monthly Bulletin, September, pp. 73-94.

Dietsch M. and Petey J. (2004) "Should SME exposures be treated as retail or corporate exposures? A comparative analysis of default probabilities and asset correlations in French and German SMEs", Journal of Banking and Finance, 28(4), pp. 773-788.

Duffie D. and Singleton K. (2003), "Credit risk: pricing, measurement and management", Princeton University Press.

European Banking Federation (2004), "ECOFIN general approach welcome but does not go far enough, says FBE", 7 December 2004.

European Central Bank (2005a), "Eurosystem collateral framework: inclusion of non-marketable assets in the Single List", Press release, 22 July 2005.

European Central Bank (2005b), "Opinion of 17 February 2005 at the request of the Council of the European Union on a proposal for directives of the European Parliament and of the Council recasting Directive 2000/12/EC of the European Parliament and of the Council of 20 March 2000 relating to the taking up and pursuit of the business of credit institutions and Council Directive 93/6/EEC of 15 March 1993 on the capital adequacy of investment firms and credit institutions $(\mathrm{CON} / 2005 / 4) "$.

European Central Bank (2005c), "Banking structures in the new EU Member States", January.

European Commission Services (2004), "Proposal for new capital requirements regime for credit institutions and investment firms", $\operatorname{COM(2004)486,~} 14$ July 2004.

European Commission (2003a), "Review of the capital requirements for credit institutions and investment firms - Third quantitative impact study: EU results", July.

European Commission (2003b), "SMEs in Europe 2003", Observatory of European SMEs, No. 7.

European Financial Services Round Table (2005), "On the lead supervisor model and the future of financial supervision in the EU", June.

European Financial Services Round Table (2004), "Towards a lead supervisor for cross-border financial institutions in the European Union", June.

European Mortgage Federation (2003), "Position Paper on November 18 Commission Working Document on capital requirements for credit institutions and investment firms", Mimeo, January. 
European Private Equity and Venture Capital Association (2005), “EVCA Yearbook 2005”, June.

European Private Equity and Venture Capital Association (2004), "Implementation of Basel II in the EU", 14 July 2004.

Fabi F., Laviola S. and Marullo-Reedtz P. (2004), "The treatment of SME loans in the new Basel capital accord: some evaluations”, Banca Nazionale del Lavoro Quarterly Review 57(228), pp. 29-70.

Federal Reserve Board, FDIC, OCC, OTS, (2005), "Banking agencies to perform additional analysis before issuing Notice of Proposed Rulemaking related to Basel II", Press Release, 29 April 2005.

Federal Reserve Board, FDIC, OCC, OTS, (2003), "Banking agencies announce revised plan for implementation of Basel II framework “, Press Release, 30 September 2003.

Ferguson R. W. (2003), "Basel II: scope of application in the United States", Remarks before the Institute of International Bankers, 10 June 2003

Goodhart C. and Segoviano M. (2004), "Basel and procyclicality: a comparison of the Standardised and IRB Approaches to an improved credit risk method", FMG Working Paper.

Gordy M. (2003), “A risk-factor model foundation for ratings-based bank capital rules”, Journal of Financial Intermediation, No. 12, pp. 199-232.

Gordy M. and Howells B. (2004), "Procyclicality in Basel II: can we treat the disease without killing the patient?", Mimeo.

Hayes S., Saporta V. and Lodge D. (2002), “The impact of the new Basel Accord on the supply of capital to emerging market economies", Bank of England, Financial Stability Review, December, pp. 112-116.

Helsinki Protocol (2000), "Protocol relating to the collaboration of the supervisory authorities of the Member States of the European Union with regard to the application of Directive 98/78/EC on the supplementary supervision of insurance undertakings in an insurance group", 11 May 2000.

Hoffmann B. (2005) "Procyclicality: the macroeconomic impact of risk-based capital requirements", Financial Markets and Portfolio Management 19(2), pp. 179-200.

Illing M. and Paulin G. (2004), "The New Basel Capital Accord and the cyclical behaviour of bank capital”, Bank of Canada, Working Paper, 2004-30.

Jackson P., Perraudin W., and Saporta V. (2002), “Regulatory and 'economic' solvency standards for internationally active banks", Journal of Banking and Finance, No. 26, pp. 953-976.

Joint Forum (1999), "Supervision of financial conglomerates", February. 
Kashyap A. and Stein J. (2003), "Cyclical implications of the Basel II capital standards", University of Chicago Working Paper.

Lowe P. (2002), “Credit risk measurement and procyclicality”, BIS, Working Paper No. 116.

Marcelo A. and Scheicher M. (2005), "Capital requirements for corporate default risk", ECB Mimeo.

Nordea (2003), "Nordea reduces complexity in its legal structure by forming one European company", Press release, 19 June 2003.

Powell D. E. (2005), "Statement of Donald E. Powell, Chairman Federal Deposit Insurance Corporation, on the Development of the New Basel Capital Accords before the Committee on Banking, Housing, and Urban Affairs", 10 November 2005.

PricewaterhouseCoopers (2004), "Study on the financial and macroeconomic consequences of the draft proposed new capital requirements for banks and investment firms in the EU, (Markt/2003/02/F), 8 April 2004.

Roesch D. (2005) "An empirical comparison of default risk forecasts from alternative credit rating philosophies", International Journal of Forecasting, 21(1), pp. 37-51.

Schmidt Bies S. (2005), “Testimony of Governor Susan Schmidt Bies before the Subcommittee on Domestic and International Monetary Policy, Trade and Technology and the Subcommittee on Financial Institutions and Consumer Credit, Committee on Financial Services, U.S. House of Representatives", 11 May 2005.

Segoviano M. and Lowe P. (2002), "Internal ratings, the business cycle and capital requirements: some evidence from an emerging market economy", BIS, Working Paper No. 117. 


\section{EUROPEAN CENTRAL BANK}

OCCASIONAL PAPER SERIES

1 "The impact of the euro on money and bond markets" by J. Santillán, M. Bayle and C. Thygesen, July 2000.

2 "The effective exchange rates of the euro" by L. Buldorini, S. Makrydakis and C. Thimann, February 2002.

3 "Estimating the trend of $\mathrm{M} 3$ income velocity underlying the reference value for monetary growth" by C. Brand, D. Gerdesmeier and B. Roffia, May 2002.

4 "Labour force developments in the euro area since the 1980s" by V. Genre and R. Gómez-Salvador, July 2002.

5 "The evolution of clearing and central counterparty services for exchange-traded derivatives in the United States and Europe: a comparison" by D. Russo, T. L. Hart and A. Schönenberger, September 2002.

6 "Banking integration in the euro area" by I. Cabral, F. Dierick and J. Vesala, December 2002.

7 "Economic relations with regions neighbouring the euro area in the "Euro Time Zone"" by F. Mazzaferro, A. Mehl, M. Sturm, C. Thimann and A. Winkler, December 2002.

8 "An introduction to the ECB's survey of professional forecasters" by J. A. Garcia, September 2003.

9 "Fiscal adjustment in 1991-2002: stylised facts and policy implications" by M. G. Briotti, February 2004.

10 "The acceding countries' strategies towards ERM II and the adoption of the euro: an analytical review" by a staff team led by P. Backé and C. Thimann and including O. Arratibel, O. Calvo-Gonzalez, A. Mehl and C. Nerlich, February 2004.

11 "Official dollarisation/euroisation: motives, features and policy implications of current cases" by A. Winkler, F. Mazzaferro, C. Nerlich and C. Thimann, February 2004.

12 "Understanding the impact of the external dimension on the euro area: trade, capital flows and other international macroeconomic linkages" by R. Anderton, F. di Mauro and F. Moneta, March 2004.

13 "Fair value accounting and financial stability" by a staff team led by A. Enria and including L. Cappiello, F. Dierick, S. Grittini, A. Maddaloni, P. Molitor, F. Pires and P. Poloni, April 2004.

14 "Measuring Financial Integration in the Euro Area" by L. Baele, A. Ferrando, P. Hördahl, E. Krylova, C. Monnet, April 2004. 
15 "Quality adjustment of European price statistics and the role for hedonics" by H. Ahnert and G. Kenny, May 2004.

16 "Market dynamics associated with credit ratings: a literature review" by F. Gonzalez, F. Haas, R. Johannes, M. Persson, L. Toledo, R. Violi, M. Wieland and C. Zins, June 2004.

17 “Corporate 'Excesses' and financial market dynamics” by A. Maddaloni and D. Pain, July 2004.

18 "The international role of the euro: evidence from bonds issued by non-euro area residents" by A. Geis, A. Mehl and S. Wredenborg, July 2004.

19 "Sectoral specialisation in the EU a macroeconomic perspective" by MPC task force of the ESCB, July 2004.

20 "The supervision of mixed financial services groups in Europe" by F. Dierick, August 2004.

21 "Governance of securities clearing and settlement systems" by D. Russo, T. Hart, M. C. Malaguti and C. Papathanassiou, October 2004.

22 "Assessing potential output growth in the euro area: a growth accounting perspective" by A. Musso and T. Westermann, January 2005.

23 "The bank lending survey for the euro area" by J. Berg, A. van Rixtel, A. Ferrando, G. de Bondt and S. Scopel, February 2005.

24 "Wage diversity in the euro area: an overview of labour cost differentials across industries" by V. Genre, D. Momferatou and G. Mourre, February 2005.

25 "Government debt management in the euro area: recent theoretical developments and changes in practices" by G. Wolswijk and J. de Haan, March 2005.

26 "The analysis of banking sector health using macro-prudential indicators" by L. Mörttinen, P. Poloni, P. Sandars and J. Vesala, March 2005.

27 “The EU budget - how much scope for institutional reform?" by H. Enderlein, J. Lindner, O. Calvo-Gonzalez, R. Ritter, April 2005.

28 "Reforms in selected EU network industries" by R. Martin, M. Roma, I. Vansteenkiste, April 2005.

29 "Wealth and asset price effects on economic activity", by F. Altissimo, E. Georgiou, T. Sastre, M. T. Valderrama, G. Sterne, M. Stocker, M. Weth, K. Whelan, A. Willman, June 2005.

30 "Competitiveness and the export performance of the euro area", by a Task Force of the Monetary Policy Committee of the European System of Central Banks, June 2005.

31 "Regional monetary integration in the member states of the Gulf Cooperation Council (GCC)" by M. Sturm and N. Siegfried, June 2005. 
32 "Managing financial crises in emerging market economies: experience with the involvement of private sector creditors" by an International Relations Committee task force, July 2005.

33 "Integration of securities market infrastructures in the euro area" by H. Schmiedel, A. Schönenberger, July 2005.

34 "Hedge funds and their implications for financial stability" by T. Garbaravicius and F. Dierick, August 2005.

35 "The institutional framework for financial market policy in the USA seen from an EU perspective" by R. Petschnigg, September 2005.

36 "Economic and monetary integration of the new Member States: helping to chart the route" by J. Angeloni, M. Flad and F. P. Mongelli, September 2005.

37 "Financing conditions in the euro area" by L. Bê Duc, G. de Bondt, A. Calza, D. Marqués Ibáñez, A. van Rixtel and S. Scopel, September 2005.

38 "Economic reactions to public finance consolidation: a survey of the literature" by M. G. Briotti, October 2005.

39 "Labour productivity in the Nordic EU countries: a comparative overview and explanatory factors - 1998-2004" by A. Annenkov and C. Madaschi, October 2005.

40 "What does European institutional integration tell us about trade integration?" by F. P. Mongelli, E. Dorrucci and I. Agur, December 2005.

41 "Trends and patterns in working time across euro area countries 1970-2004: causes and consequences" by N. Leiner-Killinger, C. Madaschi and M. Ward-Warmedinger, December 2005 .

42 "The New Basel Capital Framework and its implementation in the European Union" by F. Dierick, F. Pires, M. Scheicher and K. G. Spitzer, December 2005. 


